\title{
Rice agronomic traits and variability induced by mutagenesis
}

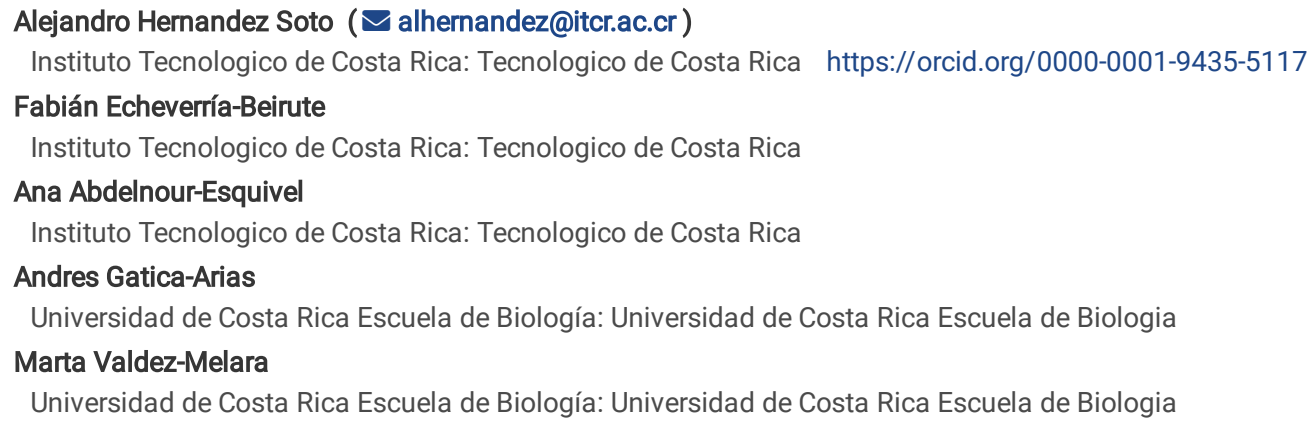

\section{Research Article}

Keywords: Mutagenesis, domestication, CRISPR, gamma radiation, chemical mutagen, biotic stress, abiotic stress

Posted Date: May 11th, 2021

DOI: https://doi.org/10.21203/rs.3.rs-513976/v1

License: (c) (i) This work is licensed under a Creative Commons Attribution 4.0 International License. Read Full License 


\section{Abstract}

Understanding agronomic traits at a genetic level enables the leveraging of this knowledge to produce crops that are more productive and resilient, have better quality and are adjusted for consumer preferences. In the last decade, rice has become a model to validate the function of specific genes, resulting in valuable but scattered information. Here, we aimed to identify particular genes in rice related to traits that can be targeted by different mutation techniques in the breeding of crops. We selected gain of function, misfunction, and specific mutations associated with phenotypes of agronomic interest. The review includes specific trait-related genes involved in domestication, stress, herbicide tolerance, pathogen resistance, grain number, quality, weight, plant structure, nitrogen use, and others. The information presented can be used for rice and crops with similar or homologous genes to breed crops that require improvement to achieve more sustainable production in challenging farming conditions.

\section{Introduction}

Induced mutagenesis is a valuable tool to support functional genomics studies and the development of new genotypes. Rice serves as an outstanding model not only because of its impact on the worldwide food supply chain but also because of the availability of technological resources to utilize. Rice was the first crop sequenced in 2004 (Matsumoto et al., 2005), biotechnological techniques are available, and the genomic information is available to search for specific target mutations, such as from the Rice Genome Annotation Project and Oryza Genome which can contribute to the precise engineering of the crop (Kawahara et al., 2013; Tanaka et al., 2020; Kajiya-Kanegae et al., 2021). Biological, chemical, and physical agents can induce mutagenesis, such as radiation, first used on vegetables in 1928; ethyl methanesulfonate (EMS), which produces 2-10 mutations per Mb; and specific mutations constructed with new breeding and genetic engineering techniques (Soriano, 1961; Serrat et al., 2014; Romero and Gatica-Arias, 2019; Viana et al., 2019; Yang et al., 2019a). In this review, we present rice traits that have emerged or been validated in the last decade (2010-2021) derived from technological advances in genomics (Benavente and Giménez, 2021). This paper is focused on characteristics that could be targeted by mutagenesis of rice lines and relatives to produce predictable variability in gains or losses of function.

\section{Methods}

The methodology applied a consistent search based on PubMed articles based on keywords: rice, traits, stress tolerance, resistance, breeding; selection of papers with agronomic traits linked to specific genes described within 2010-2021. Finally, verification of each gene, trait, and mutation was performed using specialized web servers such as Gramene, EnsemblPlants, Rice Diversity, FunRiceGenes, Rice Genome Annotation Project, Oryza Base, and Rice Information GateWay. The search resulted in a selection of 117 papers out of 500 .

\begin{tabular}{|ll|}
\hline Webserver & Link \\
\hline Gramene & https://ensembl.gramene.org/genome_browser/index.html \\
\hline EnsembIPlants & http://plants.ensembl.org/index.html \\
\hline Rice Diversity & http://www.ricediversity.org/data/index.cfm \\
\hline FunRiceGenes & http://funricegenes.ncpgr.cn/ \\
\hline Rice Genome Annotation Project, Michigan State University & http://rice.plantbiology.msu.edu \\
\hline Oryza Base & https://shigen.nig.ac.jp/rice/oryzabase/ \\
\hline Rice Information GateWay & http://rice.hzau.edu.cn/ \\
\hline
\end{tabular}

\section{Important For Breeding Rice}

Rice, such as many other tropical crops, is susceptible to a large set of biotic (fungi, bacteria, nematodes, insects, and viruses) and abiotic (salinity, drought, heat, and cold) stresses that cause yield and economic losses (Fig. 1). In general, biotic stress cause losses worldwide up to $35 \%$ of the total food production (Bainsla and Meena, 2016). As an example, losses in rice due to insects can account for over $40 \%$. Moreover, losses caused by Magnaporthe grisea, Thanatephorus cucumeris, and C. miyabeanus have been estimated worldwide at $35 \%, 24 \%$, and $16 \%$, respectively (Oerke and Dehne, 2004). On the other hand, abiotic stress represents the primary cause of crop losses worldwide, and yield losses can be as high as $50 \%$ of crop production (Ashraf et al., 2008).

In this sense, the generation of rice-resistant varieties to biotic and abiotic conditions represents one of the challenges that breeders face. For decades, breeding strategies include selection, hybridization, mutation induction using chemical and physical agents, and somaclonal variation. More recently, the availability of genome editing technologies, genome sequences, efficient tissue culture, and transformation methodologies could remarkably facilitate the breeding of rice (Fig. 2).

\section{Rice Breeding Systems}

Several methods are available for breeding rice with natural or induced mutagenesis; among them, we can mention mutation breeding, tissue culture, and new breeding techniques (CRISPR, base editing, and prime editing) (Fig. 2).

Mutation breeding 
The mutation breeding principle is to generate heritable changes in the DNA by external agents. The changes result by exposing plant cells to physical (UV, Xray, gamma radiation) or chemical (sodium azide and ethyl methanesulfonate) agents (Mba et al., 2010). Induced mutagenesis offers a promising alternative for developing rice varieties resistant to biotic and abiotic stresses since it could accelerate the spontaneous mutation process and increase the pool of genes available for genetic improvement(Gressel and Levy, 2006; Oladosu et al., 2016; Viana et al., 2019).

\section{Tissue culture}

Totipotency, a distinguishable characteristic of plant cells, allows each cell to regenerate an entire plant in principle. This process involves the culture on special growth media of tissue fragments or individual cells from a plant enabling the cells to grow and further division (Fehér, 2019). In this sense, tissue culture approaches are helpful to develop biotic or abiotic stress-tolerant plants. Among the techniques available, somaclonal variation enables changes in the DNA causing genetic and phenotypic variation among clonally propagated plants. The somaclonal variants obtained could be detected using in vitro selection by applying selective pressure in culture conditions (Larkin and Scowcroft, 1981; Bairu et al., 2011).

New breeding techniques

\section{CRISPR/Cas9}

The clustered regularly interspaced short palindromic repeats (CRISPR)-associated endonuclease Cas9 (CRISPR/Cas9) system targets a specific genomic sequence using an engineered 20 base pair (bp) RNA guide sequence that binds to its DNA and the Cas 9 , from S. pyogenes, recognizes the PAM sequence $5 \dot{c}$ NGG-3C generating double-stranded breaks in specific genes at desired locations in the genome. This genome editing method allows the insertion, deletion, or modification of DNA with increased specificity and efficiency (Romero and Gatica-Arias, 2019).

\section{CRISPR/Cpf1 system}

The nuclease Cas12a requires a small crRNA for inducing double strand breaks with efficiencies similar to those of CRISPR/Cas9. Moreover, this nuclease uses a 22 nt spacer for its maximum efficiency and specificity and identifies a T-rich PAMs located upstream of the guide and generated staggered ends (Schindele et al., 2018).

\section{Base editing}

This system allows the conversion of nucleotides without inducing double-stranded DNA breaks or using donor templates. In this sense, it has been used for changing a C-G base pair into T-A, or A-T into G-C (Marx, 2018).

\section{Prime editing}

This system uses a catalytically impaired Cas9 endonuclease fused to a reverse transcriptase enzyme, and a prime editing guide RNA (pegRNA). This complex is capable of identifying the target site and replace the target DNA nucleotides without double-stranded DNA breaks or using donor templates(Anzalone et al., 2019; Lin et al., 2020).

\section{Agronomic Traits Of Interest}

\section{Domestication genes}

The Oryza genus is composed of species with a variety of genome structures, including six diploids ( $\mathrm{n}=12$; named $\mathrm{AA}, \mathrm{BB}, \mathrm{CC}$, ee, ff, gg) and five polyploids ( $\mathrm{n}$ = 24, named BBCC, CCDD, HHJJ, HHKK, and KKLL) (Kim et al., 2015; Nadir et al., 2017; Wing et al., 2018; Chen et al., 2019). Only two diploid (2n=24) species of rice have been domesticated and used for cultivation: Oryza sativa and African $O$. glaberrima. Rice domestication emerged because of the selection of specific genes and the loss of function of specific genes. Wild relatives have functional versions of genes such as sh4, waxy, BH4, qSH1, AN1, brown pericarp, PROG1, and OsG1, as described in the following text. The sh4 gene is related to reduced seed shattering (Os04g0670900). The waxy gene controls the amylose content (Os06g0133000). BH4 is related to the hull color of the seeds (Os04g0460200). The gene qSH1 is involved in seed shattering (Os01g0848400). The AN1 gene is related to seeds, morphology, and grain shape (Os04g0350700). RC Brown pericarp is involved in the seed coat (0s07g0211500). PROG1 is related to an erect plant structure (Os07g0153600). OsLG1 is related to a closed-panicle structure (Os04g0656500) (Li et al., 2017). The importance of such genes is critical in understanding how de novo domestication and their further use in plant breeding can be achieved from wild Oryza varieties.

This concept was demonstrated even in polyploid O. alta (CCDD) by (Yu et al., 2021a), targeting SD1, GS3, IPA1, Ghd7, Gn1a, Wx, Bh4, TAC1, An-1 homologs, as well as African landraces of Oryza glaberrima by disrupting the HTD1 (O. sativa Os04g0550600), GS3 (O. sativa Os03g0407400), GW2 (0. sativa Os01g0197700) and GN1A (O. sativa Os02g0244100) genes (Lacchini et al., 2020). In terms of plant breeding, having access to nondomesticated, more genetically diverse rice species that better adapt to stress conditions, such as African landraces O. glaberrima, O. barthii, O. meridionalis (AA), Australian landraces 0 . longistaminata (AA), O. australiensis (EE), and Asian landraces O. rufipogon (AA) or Porteresia coarctata (O.coarctata) (KKLL), enables the potential of developing more sustainable rice crops (Reddy et al., 2017; Mammadov et al., 2018).

\section{Stress tolerance}

Rice susceptibility to salt is evidenced by a yield decrease due to delays in heading and panicle sterility specially in salt-sensitive varieties like MI48. In contrast, salt tolerance varieties like IR29, Fatmawati, Pokkali, Cheriviroppu, FL478, IR651, CSR27, FL30, Fontan, SR86, IR9884-54-3results from ion exclusion, osmotic and tissue tolerance with multiple genes involved in the process, which confers agronomic stability (Takagi et al., 2015; Reddy et al., 2017; Zhang et 
al., 2019a; Qin et al., 2020). The orchestrated stress system is a perfect target for achieving salt tolerance by knocking out key transcription factors, specifically OsRR22 (Os06g0183100), STL1 (Os04g0110600), and zinc finger transcription factor DST (Os03g0786400) (Cui et al., 2015; Zhang et al., 2019a; Liu et al., 2020b; Santosh Kumar et al., 2020; Yuan et al., 2020). Other transcription factors are critical in stress adaptation, which results in stress sensitivity when knocked out. This is the case for MSL37(Os11g0163500), P5CS(Os05g0455500), which produces proline accumulation out of external ABA application, the transcription factor SNAC2 (Os01g0884300), which is key in root adaptation, and OsNAP(Os03g0327800), which triggers a stress response mediated by ABA (Takasaki et al., 2010; Sripinyowanich et al., 2013; Chen et al., 2014; Lee et al., 2017; Nuñez-Muñoz et al., 2021). For details, check Figure 3 and Table 1 below.

Osmoprotection by accumulating molecules such as trehalose is a possible pathway involved in salt tolerance, as proven currently in Arabidopsis (Li et al., 2011b; Nuñez-Muñoz et al., 2021). Other individual genes could be of interest, such as the Na+ transporter SKC1 (Os01g0307500) with a V395 that provides salt tolerance (Jayabalan et al., 2019). Knocking out an independent but closely related gene, OsEPFL9 (Os01g0824500), results in increased water use efficiency under stress because of the reduced stomatal count(Yin et al., 2017, 2019).

Other stress tolerance pathways have been shown to be effective. Low cadmium accumulation occurs after knocking out the metal transporter genes OsNramp5 (Os07g0257200) and OsNramp1 (Os07g0258400); the plants are able to resist heat stress when the gene OsNTL3(Os01g0261200) is working correctly cold tolerance results from knockout of the OsMYB30 (Os02g0624300) gene and more cuticle wax is deposited when the gene DHS (OsO2g0682300) is knocked out (Sasaki et al., 2012; Tang et al., 2017; Wang et al., 2018a; Chang et al., 2020; Liu et al., 2020a; Zeng et al., 2020).

\section{Herbicide resistance monogenic traits}

Rice is usually cultivated under two agronomical systems: paddy transplanted rice (PTR) and dry seeded rice (DSR). The first is the conventional method, which requires water flooding and represents a sustainability issue because of water scarcity, methane production and the consumption of nonrenewable energy (Wang et al., 2017). DSR, on the other hand, represents opportunities for efficient water and nitrogen use, and a reduction of both greenhouse gas emissions and labor demand, especially in countries such as China, where $90 \%$ of rice is currently produced under PTR (Shekhawat et al., 2020). However, weed management is a challenge in DRS, specifically during the first 41 days after sowing (DAS). Another complication is weedy rice ( $O$. sativa $f$. spontanea), which can result in yield losses of up to $50 \%$ (Nadir et al., 2017). Weedy rice usually involves increased seed longevity, seed shattering and stress tolerance (Durand-Morat et al., 2018). The use of chemical control represents a tool to manage weedy rice, but there are still challenges as described below.

The Herbicide Resistance Action Committee (HRAC) and the Weed Science Society of America (WSSA) classify herbicides into 34 groups and one unknown group based on their "mode of action" (MoA) at the biochemical level (Forouzesh et al., 2015; Dayan et al., 2019; Gaines et al., 2020). The discovery of a new mode of action has been rare in the last 30 years. A good example is leptospermone, and its analog inhibitors act as hydroxyphenylpyruvate inhibitors of dioxygenase (HPPD) (Dayan and Duke, 2020). Different modes of herbicide action, such as rotations, delay the emergence of herbicide-resistant weeds. However, weeds are evolving to resist multiple MoA types of herbicides. For example, Chloris radiata is found in Colombian rice fields with dual resistance to glyphosate (mode of action 9) and the acetolactate synthase (ALS) inhibitor imazomox (mode of action 2) (Hoyos et al., 2021). Weedy rice infestation in the USA resulted in 5.7 million tons lost and $\$ 457$ million in environmental costs between 2002-2014 (Bzour et al., 2018). Mutations to provide herbicide tolerance were introduced into rice 20 years ago based on the Acetohydroxy acid synthase AHAS/ALS(Os02g0510200) gene mutation, providing tolerance to the mode of action 2 (Li et al., 2019). Rice herbicide tolerance varieties are used in the USA (700,000 Ha), Brazil (600,000 Ha), Uruguay (70,000 Ha), Argentina (32,000 $\mathrm{Ha})$, Malaysia $(95,000 \mathrm{Ha})$, and Italy $(60,000 \mathrm{Ha})$, as well as in many Central America countries, such as Costa Rica, Honduras, Panamá, and the Dominican Republic (Singh et al., 2017). The incorrect use of this variety allowed introgression and outcrossing of the resistance into red rice, which means that weed herbicide control requires stricter farming practices, such as rotation (Liu et al., 2021). Alternatives such as aryloxphenoxy propionate-resistant rice (mode of action 1), which is the result of mutations in the ACCase2 (Os5g0295300) gene, already exist and will allow for herbicide rotation (de Andrade et al., 2018; Camacho et al., 2019).

According to the literature, at least five target genes have the potential to develop herbicide-resistant rice varieties with a different mode of action. Two of those have already been described previously: ACCase2 on aryloxphenoxy propionates (MoA-1) and AHAS/ALS on ALS (MoA-2). The first ACCase2 includes mutations such as I1781L, S1866F, I1879V, A1884P, W2027C, W2125S, D2176G, and C2186R/P1927F/G2201A/W2125C at exon 32 that provides tolerance at a different rate. The second AHAS/ALS results in ALS MoA-2 resistance when carrying the following mutations: A96V/A122T/P171H/P171S/P197S/C287T and W548L/W574L/S627I/S653I/S653N/G654E. The third OsTubA2 (Os11g0247300) with a mutation in the fourth exon, M268T, providing tolerance to dinitroanilines (MoA-3). Another gene, HPPD (Os02g0280700), provides tolerance to triketones when there is a natural insertion site (GGAACCAAAAGAATTAGAGACGATATCA) in the fourth exon. Finally, the double mutation known as "TIPS" (T102I+P106S) in the OsEPSPS(Os02g0510200) gene provides tolerance to MoA-9. For details, check Figure 4 and Table 2 below.

Herbicide-resistant weeds to the inhibition of photosynthesis at PSIl can also provide insights for rice models. The S264G mutation in $p s b A$ increases tolerance more than 50-fold in triazine herbicide-tolerant radish (MoA-5). However, it can also compromise fitness because of less efficient photosynthesis (Lu et al., 2019). Other mutations, such as Val219lle, Asn266Thr, Phe255Ile, and Ala251Val, can also provide tolerance (Gaines et al., 2020). It is important to note that the $p s b A$ mutation Val-219-lle provides tolerance to the amide propanil MoA-5 on Cyperus difformis (Pedroso et al., 2016). Propanil is widely used in rice cultivation because the crop is naturally capable of degrading the molecule by a putative enzyme located in the mitochondria, and an additional resistance pathway could increase its efficiency (Matsunaka, 1967; Chen and Matsunaka, 1990). The described mutations could also result in herbicide tolerance in rice when targeting the homologous gene AAS46167, encoding protein P0C434, to address an additional MoA.

Rice is also known to be resistant to Bentazon (MoA-6), as it is degraded by cytochrome P450 CYP81A6 (Pan et al., 2006). Additionally, the P450 gene CYP72A31 is responsible for conferring tolerance to bispyribac sodium (BS) in Oryza sativa indica, while its absence in japonica rice varieties results in BSsensitive varieties (Zhang et al., 2002; Saika et al., 2014). 


\section{Bacteria, fungi and virus resistance}

Rice breeding of pathogen resistance is possible by knockout of the Sweet 14,11,13 genes named Os11g0508600, Os08g0535200, Os 12g0476200, respectively, since they act as a point of access for pathogens causing bacterial blight streaks (BLSs), such as Xanthomonas oryzae pv. oryzae (Xoo), and they reduce copper in the xylem (Jiang et al., 2013; Oliva et al., 2019; Varshney et al., 2019). The pathogen emerges by breaking the resistance pressure of varieties planted in approximately $80 \%$ of the total crop cultivation area carrying the resistance gene Xa4 on chromosome 11 introduced in the 60 s in the variety IR20 (Quibod et al., 2020) Xanthomonas oryzae can also infect wild grasses and become an emergent microorganism that is difficult to control (Lang et al., 2019).

Another outstanding gene to target is the transcription factor IPA1 (Os08g0509600); higher expression levels of IPA1 result in increased yield and immunity when tested against Magnaporthe oryzae. Resistance relies on time- and pathogen-specific phosphorylated activation of the transcription factor at Ser163 and subsequent WRKY45 promoter-resistant gene triggering within 48 hours after infection, while the yield of the nonphosphorylated protein binds to the DEP1 promoter (Jing Wang et al., 2018). A different way to achieve M. oryzae resistance is by knocking out OsERF922 ethylene response factor 922 (Os01g0752500) (Wang et al., 2016). For details, see Table 3 below.

\section{Grain number, quality, weight and plant structure}

Rice quality traits are essential to achieve a better yield, consumer preference, and growth efficiency. The genes involved in grain number and size, plant density, structure, panicles, and flowering are complex because of their interactions. However, new findings and key mutations provide some insights into their regulatory mechanisms and greater predictability in achieving the desired phenotype, as described next (for details, see Figure 5 and Table 4 below).

Grain size. The GS3 Grain Size3 gene (Os03g0407400) is responsible for negatively controlling the grain length. Its mutation can result in better or worse weight and size that correlates with the composition of its domains: organ size regulation (OSR), a transmembrane necrosis factor receptor/nerve growth factor receptor (TNFR/NGFR), and a von Willebrand factor type C (VWFC) (Takano-Kai et al., 2013; Li et al., 2016; Shen et al., 2017; Yang et al., 2019b; Zeng et al., 2020). The wild type allele contains all of the domains and results in medium grains (Takano-Kai et al., 2013). Loss of function results in long-grain varieties; for example, Minghui 63 has a stop mutation C165A at the second exon, resulting in a loss of function and a long-grain phenotype. In contrast, a mutation or deletion in the fifth exon creates a truncated protein with no VWFC domain and a short seed phenotype (Mao et al., 2010; Takano-Kai et al., 2013). A directed mutation that knocks out the gene results in a larger grain size (Li et al., 2016; Zeng et al., 2020). Size, in general, is also controlled by several genes: higher expression of GW6a (Os06g0650300), and knockout of GW5 (Os05g0187500), GW6 (Os06g0623700), and GW5L (Os01g0190500) results in increased grain size (Ishimaru et al., 2013; Song et al., 2015; Tian et al., 2019; Zhang et al., 2020; Ayaad et al., 2021).

Grain number. Malfunction of the gene Os01g0197700 (GN1a) produces an increment of grain per panicle number and flowering because of a lower degradation of cytokines produced by the corresponding cytokinin oxidation enzyme (Li et al., 2016; Shen et al., 2017; Huang et al., 2018). Another gene that correlates with increased production and downregulates cytokine level regulation is EP3 Erect Panicle 3(Os02g0260200) (Li et al., 2011a; Shen et al., 2017).

Grain starch. Another essential trait in grains is starch quality, which depends on the right mixture of amylose and protein. The global starch content relies on the gene ISA1 (Os08g0520900) and the protein content relies on NAC20-26 (Os01g0104500, Os01g0393100) (Shufen et al., 2019; Wang et al., 2020). The waxy gene WX1 (Os06g0133000) controls the grain amylose content (AC). Mutations in this gene correlate with a phenotype that ranges from opaque (8\%), semitranslucent (8-12\%), and transparent (12\% or more) grains (Sano, 1984; Yunyan et al., 2019; Zhang et al., 2019b; Huang et al., 2020; Xu et al., 2021).

Flowering. Flowering and photoperiodic insensitivity results from overexpression of OsMeCP (Os12g0620400 (Qu et al., 2021) or by knocking out several genes. For example, Se5, Hd2 and Hd1 (Andrés et al., 2009; Gao et al., 2014; Shen et al., 2017; Tanaka et al., 2020). Another critical regulator of heading date and grain weight seems to be $H G W$, and its homozygous null mutant is embryonic lethal (Li et al., 2012).

Structure. Farmers prefer smaller plants with many panicles and fewer tillering traits. Knockout of the DEP1 (Os09g0441900) gene, as well as the loss of function of the HTD1 (Os04g0550600) gene coming from landraces produces short, dense, erect panicles (Zou et al., 2006; Li et al., 2016; Lacchini et al., 2020).

The transcription factor IPA1 Ideal Plant Architecture1 (Os08g0509600) -specific mutations between bases 854 and 876 can increase the expression of transcription factor proteins because they interrupt OsmiR156 transcript cleavage. For example, C874A in the third exon (leucine to isoleucine) generates a rice plant with a reduced tiller number, increased lodging resistance, and an enhanced grain yield (Li et al., 2016; Wang et al., 2018b).

The number of panicles and consequently the yield can be increased by knocking out or indirectly blocking Pin $1 A$ and $P$ in $15 b$. The indirect mechanism results in higher expression of DEP1 and LPA1, which interact to suppress PIN1a expression (Huang et al., 2018; Fu et al., 2019; Miao Liu et al., 2020). LPA1 is also important in the erect phenotype, and its knockout results in lamina inclination, while BAS1 seems to be important in stomata closing (Liu et al., 2016; Mao et al., 2018).

\section{Other traits}

Other rice traits provide value for breeding and for satisfying consumer preferences, such as nitrogen use, fragrancy, oleic acid content, and color. Regarding nitrogen, there is a better efficiency with a higher expression of the nitrate transporter OSNPF6.1 and the two transcription factors OsNAC42 and OsNLP4 (Tang et al., 2019; Yu et al., 2021b). Knockout of the FAD2 gene results in an oleic acid increment (Tiwari et al., 2016; Abe et al., 2018). Furthermore, a mutation in the Osor (Os02g0651300) gene results in potential orange-colored rice (Endo et al., 2019), and fragrancy can be increased or decreased by modulating the BADH2 gene, which prevents the formation of the aromatic compound 2AP (2-acetyl-1-pyrroline) (Shen et al., 2017). For details, check Table 5 below. 


\section{Conclusion}

Induced mutations targeting specific genes associated with known phenotypes, as described in this review, will allow for advances in more precise rice breeding to improve the varieties that farmers are already using. It can also result in new varieties and de novo domestication from wild relatives and extrapolate the results to other crops with homologous traits. Farmers urgently requires advances in this knowledge to respond to the challenges of climate change, consumer demands, water scarcity, nitrogen usage, and sustainable production.

\section{List Of Abbreviations}

Ethyl methanesulfonate (EMS)

Puddled Transplanted Rice (PTR)

Dry Seeded Rice (DSR)

Days After Sowing (DAS)

The Herbicide Resistance Action Committee (HRAC)

Weed Science Society of America (WSSA)

Mode of Action (MoA)

Bacterial Blight Streak (BLS)

Amylose Content (AC)

Acetolactate Synthase (ALS)

NUE (nitrogen use efficiency).

\section{Declarations}

Ethics approval and consent to participate 'Not applicable'

Consent for publication 'Not applicable'

Availability of data and material 'Not applicable'

Competing interests "The authors declare that they have no competing interests"

Funding This paper was funded by the Project 1510-1022. Research Vice-Rectory of TEC, Costa Rica, and is part of the Doctoral Thesis of the first author, Doctorado en Ciencia Naturales para el Desarrollo (DOCINADE), Instituto Tecnológico de Costa Rica, Universidad Nacional, Universidad Estatal a Distancia, Cartago, Costa Rica.

Authors' contributions A.H.-S conceived the paper, designed and coordinated the inputs, analyzed the data, and wrote the manuscript; F.E.-B reviewed, discussed the content and edited the paper; A. A-E discussed the results and edited the paper; A.G.-A. wrote, reviewed, discussed the results and edited the paper; M.V.-M. discussed the results and edited the paper. All authors read and approved the final manuscript.

\section{Acknowledgments}

Not applicable.

\section{References}

Abe, K., E. Araki, Y. Suzuki, S. Toki, and H. Saika. 2018. Production of high oleic/low linoleic rice by genome editing. Plant Physiology and Biochemistry 131(April): 58-62. doi: 10.1016/j.plaphy.2018.04.033.

de Andrade, A., A. Tulmann-Neto, F.A. Tcacenco, R. Marschalek, A. Pereira, et al. 2018. Development of rice (Oryza sativa) lines resistant to aryloxyphenoxypropionate herbicides through induced mutation with gamma rays. Plant Breeding 137(3): 364-369. doi: 10.1111/pbr.12592.

Andrés, F., D.W. Galbraith, M. Talón, and C. Domingo. 2009. Analysis of Photoperiod Sensitivity 5 sheds light on the role of phytochromes in photoperiodic flowering in rice. Plant Physiology 151(2): 681-690. doi: 10.1104/pp.109.139097.

Anzalone, A. v, P.B. Randolph, J.R. Davis, A.A. Sousa, L.W. Koblan, et al. 2019. Search-and-replace genome editing without double-strand breaks or donor DNA. Nature. doi: 10.1038/s41586-019-1711-4. 
Ashraf, M., H.R. Athar, P.J.C. Harris, and T.R. Kwon. 2008. Some Prospective Strategies for Improving Crop Salt Tolerance. Advances in Agronomy 97(07): 45110. doi: 10.1016/S0065-2113(07)00002-8.

Ayaad, M., Z. Han, K. Zheng, G. Hu, M. Abo-Yousef, et al. 2021. Bin-based genome-wide association studies reveal superior alleles for improvement of appearance quality using a 4-way MAGIC population in rice. Journal of Advanced Research 28: 183-194. doi: 10.1016/j.jare.2020.08.001.

Bainsla, N.K., and H.P. Meena. 2016. Breeding for Resistance to Biotic Stresses (J. v Yadav P, Kumar S, editor). Daya Publishing House, New Delhi.

Bairu, M.W., A.O. Aremu, and J. van Staden. 2011. Somaclonal variation in plants: Causes and detection methods. Plant Growth Regulation 63(2): 147-173. doi: 10.1007/s10725-010-9554-x.

Benavente, E., and E. Giménez. 2021. Modern Approaches for the Genetic Improvement of Rice, Wheat and Maize for Abiotic Constraints-Related Traits: A Comparative Overview. Agronomy 11(2): 376. doi: 10.3390/agronomy11020376.

Bzour, M.I., F.M. Zuki, and M.S. Mispan. 2018. Introduction of imidazolinone herbicide and Clearfield® rice between weedy rice-control efficiency and environmental concerns.

Camacho, J.R., S.D. Linscombe, Y. Sanabria, P.A. Mosquera, and J.H. Oard. 2019. Inheritance of Provisia' ${ }^{\text {TM }}$ rice resistance to quizalofop-p-ethyl under laboratory and greenhouse environments. Euphytica 215(4). doi: 10.1007/s10681-019-2407-4.

Chang, J.D., S. Huang, N. Yamaji, W. Zhang, J.F. Ma, et al. 2020. OsNRAMP1 transporter contributes to cadmium and manganese uptake in rice. Plant Cell and Environment 43(10): 2476-2491. doi: 10.1111/pce.13843.

Chen, E., X. Huang, Z. Tian, R.A. Wing, and B. Han. 2019. The Genomics of Oryza Species Provides Insights into Rice Domestication and Heterosis. Annual Review of Plant Biology 70: 639-665. doi: 10.1146/annurev-arplant-050718-100320.

Chen, J.J., and S. Matsunaka. 1990. The propanil hydrolyzing enzyme aryl acylamidase in the wild rices of genus Oryza. Pesticide Biochemistry and Physiology 38(1): 26-33. doi: 10.1016/0048-3575(90)90144-Q.

Chen, X., Y. Wang, B. Lv, J. Li, L. Luo, et al. 2014. The NAC family transcription factor OsNAP confers abiotic stress response through the ABA pathway. Plant and Cell Physiology 55(3): 604-619. doi: 10.1093/pcp/pct204.

Cui, L.G., J.X. Shan, M. Shi, J.P. Gao, and H.X. Lin. 2015. DCA1 Acts as a Transcriptional Co-activator of DST and Contributes to Drought and Salt Tolerance in Rice. PLoS Genetics 11(10): 1-22. doi: 10.1371/journal.pgen.1005617.

Dayan, F.E., A. Barker, R. Bough, M. Ortiz, H. Takano, et al. 2019. Herbicide mechanisms of action and resistance. Third Edit. Elsevier.

Dayan, F.E., and S.O. Duke. 2020. Discovery for New Herbicide Sites of Action by Quantification of Plant Primary Metabolite and Enzyme Pools. Engineering 6(5): 509-514. doi: 10.1016/j.eng.2020.03.004.

Durand-Morat, A., L.L. Nalley, and G. Thoma. 2018. The implications of red rice on food security. Global Food Security 18(April): 62-75. doi: 10.1016/j.gfs.2018.08.004.

Endo, A., H. Saika, M. Takemura, N. Misawa, and S. Toki. 2019. A novel approach to carotenoid accumulation in rice callus by mimicking the cauliflower Orange mutation via genome editing. Rice 12(1): 1-5. doi: 10.1186/s12284-019-0345-3.

Fehér, A. 2019. Callus, dedifferentiation, totipotency, somatic embryogenesis: What these terms mean in the era of molecular plant biology? Frontiers in Plant Science 10. doi: 10.3389/fpls.2019.00536.

Forouzesh, A., E. Zand, S. Soufizadeh, and S. Samadi Foroushani. 2015. Classification of herbicides according to chemical family for weed resistance management strategies-an update. Weed Research 55(4): 334-358. doi: 10.1111/wre.12153.

Fu, X., J. Xu, M. Zhou, M. Chen, L. Shen, et al. 2019. Enhanced expression of QTL qLL9/DEP1 facilitates the improvement of leaf morphology and grain yield in rice. International Journal of Molecular Sciences 20(4). doi: 10.3390/ijms20040866.

Gaines, T.A., S.O. Duke, S. Morran, C.A.G. Rigon, P.J. Tranel, et al. 2020. Mechanisms of evolved herbicide resistance. Journal of Biological Chemistry 295(30): 10307-10330. doi: 10.1074/jbc.REV120.013572.

Gao, H., M. Jin, X.M. Zheng, J. Chen, D. Yuan, et al. 2014. Days to heading 7, a major quantitative locus determining photoperiod sensitivity and regional adaptation in rice. Proceedings of the National Academy of Sciences of the United States of America 111(51): 18399-18400. doi: 10.1073/pnas.1422341112.

Gressel, J., and A.A. Levy. 2006. Agriculture: The selector of improbable mutations. Proceedings of the National Academy of Sciences of the United States of America 103(33): 12215-12216. doi: 10.1073/pnas.0603666103.

Hoyos, V., G. Plaza, J.G. Vázquez-Garcia, C. Palma-Bautista, A.M. Rojano-Delgado, et al. 2021. Confirmation of Multiple Resistant Chloris radiata Population, Harvested in Colombian Rice Fields. Agronomy 11(3): 496. doi: 10.3390/agronomy11030496.

Huang, L., N. Sreenivasulu, and Q. Liu. 2020. Waxy Editing: Old Meets New. Trends in Plant Science 25(10): 963-966. doi: 10.1016/j.tplants.2020.07.009. 
Huang, L., R. Zhang, G. Huang, Y. Li, G. Melaku, et al. 2018. Developing superior alleles of yield genes in rice by artificial mutagenesis using the CRISPR/Cas9 system. Crop Journal 6(5): 475-481. doi: 10.1016/j.cj.2018.05.005.

Ishimaru, K., N. Hirotsu, Y. Madoka, N. Murakami, N. Hara, et al. 2013. Loss of function of the IAA-glucose hydrolase gene TGW6 enhances rice grain weight and increases yield. Nature Genetics 45(6): 707-711. doi: 10.1038/ng.2612.

Jayabalan, S., S. Pulipati, K. Ramasamy, D. Jaganathan, S.D. Venkatesan, et al. 2019. Analysis of genetic diversity and population structure using SSR markers and validation of a Cleavage Amplified Polymorphic Sequences (CAPS) marker involving the sodium transporter OsHKT1;5 in saline tolerant rice (Oryza sativa L.) landraces. Gene 713(July): 143976. doi: 10.1016/j.gene.2019.143976.

Jiang, W., H. Zhou, H. Bi, M. Fromm, B. Yang, et al. 2013. Demonstration of CRISPR/Cas9/sgRNA-mediated targeted gene modification in Arabidopsis, tobacco, sorghum and rice. Nucleic Acids Research 41(20): 1-12. doi: 10.1093/nar/gkt780.

Kajiya-Kanegae, H., H. Ohyanagi, T. Ebata, Y. Tanizawa, A. Onogi, et al. 2021. OryzaGenome2.1: Database of Diverse Genotypes in Wild Oryza Species. Rice 14(1). doi: 10.1186/s12284-021-00468-x.

Kawahara, Y., M. de la Bastide, J.P. Hamilton, H. Kanamori, W.R. Mccombie, et al. 2013. Improvement of the oryza sativa nipponbare reference genome using next generation sequence and optical map data. Rice 6(1): 3-10. doi: 10.1186/1939-8433-6-4.

Kim, K., S.C. Lee, J. Lee, Y. Yu, K. Yang, et al. 2015. Complete chloroplast and ribosomal sequences for 30 accessions elucidate evolution of Oryza AA genome species. Scientific Reports 5(September): 1-13. doi: 10.1038/srep15655.

Lacchini, E., E. Kiegle, M. Castellani, H. Adam, S. Jouannic, et al. 2020. CRISPR-mediated accelerated domestication of African rice landraces. PLoS ONE 15(3): 1-12. doi: 10.1371/journal.pone.0229782.

Lang, J.M., A.L. Pérez-Quintero, R. Koebnik, E. DuCharme, S. Sarra, et al. 2019. A pathovar of Xanthomonas oryzae infecting wild grasses provides insight into the evolution of pathogenicity in rice agroecosystems. Frontiers in Plant Science 10(April): 1-15. doi: 10.3389/fpls.2019.00507.

Larkin, P.J., and W.R. Scowcroft. 1981. Somaclonal variation - a novel source of variability from cell cultures for plant improvement. Theoretical and Applied Genetics 60(4): 197-214. doi: 10.1007/BF02342540.

Lee, D.K., P.J. Chung, J.S. Jeong, G. Jang, S.W. Bang, et al. 2017. The rice OsNAC6 transcription factor orchestrates multiple molecular mechanisms involving root structural adaptions and nicotianamine biosynthesis for drought tolerance. Plant Biotechnology Journal 15(6): 754-764. doi: 10.1111/pbi.12673.

Li, J., H. Chu, Y. Zhang, T. Mou, C. Wu, et al. 2012. The rice HGW gene encodes a ubiquitin-associated (UBA) domain protein that regulates heading date and grain weight. PLoS ONE 7(3). doi: 10.1371/journal.pone.0034231.

Li, L.F., Y.L. Li, Y. Jia, A.L. Caicedo, and K.M. Olsen. 2017. Signatures of adaptation in the weedy rice genome. Nature Genetics 49(5): 811-814. doi: 10.1038/ng.3825.

Li, M., X. Li, Z. Zhou, P. Wu, M. Fang, et al. 2016. Reassessment of the four yield-related genes Gn1a, DEP1, GS3, and IPA1 in rice using a CRISPR/Cas9 system. Frontiers in Plant Science 7(MAR2016): 1-13. doi: 10.3389/fpls.2016.00377.

Li, F., A. Shimizu, T. Nishio, N. Tsutsumi, and H. Kato. 2019. Comparison and characterization of mutations induced by gamma-ray and carbon-ion irradiation in rice (Oryza sativa L.) using whole-genome resequencing. G3: Genes, Genomes, Genetics 9(11): 3743-3751. doi: 10.1534/g3.119.400555.

Li, M., D. Tang, K. Wang, X. Wu, L. Lu, et al. 2011a. Mutations in the F-box gene LARGER PANICLE improve the panicle architecture and enhance the grain yield in rice. Plant Biotechnology Journal 9(9): 1002-1013. doi: 10.1111/j.1467-7652.2011.00610.x.

Li, H.W., B.S. Zang, X.W. Deng, and X.P. Wang. 2011b. Overexpression of the trehalose-6-phosphate synthase gene OsTPS1 enhances abiotic stress tolerance in rice. Planta 234(5): 1007-1018. doi: 10.1007/s00425-011-1458-0.

Lin, Q., Y. Zong, C. Xue, S. Wang, S. Jin, et al. 2020. Prime genome editing in rice and wheat. Nature Biotechnology 38(5): 582-585. doi: 10.1038/s41587-0200455-x.

Liu, L., Y. Kuang, F. Yan, S. Li, B. Ren, et al. 2021. Developing a novel artificial rice germplasm for dinitroaniline herbicide resistance by base editing of OsTubA2. Plant Biotechnology Journal 19(1): 5-7. doi: 10.1111/pbi.13430.

Liu, X.H., Y.S. Lyu, W. Yang, Z.T. Yang, S.J. Lu, et al. 2020a. A membrane-associated NAC transcription factor OsNTL3 is involved in thermotolerance in rice. Plant Biotechnology Journal 18(5): 1317-1329. doi: 10.1111/pbi.13297.

Liu, J.M., S.J. Park, J. Huang, E.J. Lee, Y.H. Xuan, et al. 2016. Loose Plant Architecture1 (LPA1) determines lamina joint bending by suppressing auxin signalling that interacts with C-22-hydroxylated and 6-deoxo brassinosteroids in rice. Journal of Experimental Botany 67(6): 1883-1895. doi:

$10.1093 / \mathrm{jxb} / \mathrm{erw002.}$

Liu, X., D. Wu, T. Shan, S. Xu, R. Qin, et al. 2020b. The trihelix transcription factor OsGTY-2 is involved adaption to salt stress in rice. Plant Molecular Biology 103(4-5): 545-560. doi: 10.1007/s11103-020-01010-1. 
Lu, H., Q. Yu, H. Han, M.J. Owen, and S.B. Powles. 2019. A novel psbA mutation (Phe274-Val) confers resistance to PSIl herbicides in wild radish (Raphanus raphanistrum). Pest Management Science 75(1): 144-151. doi: 10.1002/ps.5079.

Mammadov, J., R. Buyyarapu, S.K. Guttikonda, K. Parliament, I.Y. Abdurakhmonov, et al. 2018. Wild Relatives of Maize, Rice, Cotton, and Soybean: Treasure Troves for Tolerance to Biotic and Abiotic Stresses. Frontiers in Plant Science 9(June). doi: 10.3389/fpls.2018.00886.

Mao, H., S. Sun, J. Yao, C. Wang, S. Yu, et al. 2010. Linking differential domain functions of the GS3 protein to natural variation of grain size in rice. Proceedings of the National Academy of Sciences of the United States of America 107(45): 19579-19584. doi: 10.1073/pnas.1014419107.

Mao, X., Y. Zheng, K. Xiao, Y. Wei, Y. Zhu, et al. 2018. OsPRX2 contributes to stomatal closure and improves potassium deficiency tolerance in rice. Biochemical and Biophysical Research Communications 495(1): 461-467. doi: 10.1016/j.bbrc.2017.11.045.

Marx, V. 2018. Base editing a CRISPR way. Nature Methods 15(10): 767-770. doi: 10.1038/s41592-018-0146-4.

Matsumoto, T., J. Wu, H. Kanamori, Y. Katayose, M. Fujisawa, et al. 2005. The map-based sequence of the rice genome. Nature 436(7052): 793-800. doi: $10.1038 /$ nature03895.

Matsunaka, S. 1967. Propanil Hydrolysis: Inhibition in Rice Plants by Insecticides. Science 160(3834): 1360-1361. doi: 10.1126/science.160.3834.1360.

Mba, C., R. Afza, S. Bado, and S.M. Jain. 2010. Induced Mutagenesis in Plants Using Physical and Chemical Agents. Plant Cell Culture: Essential Methods (March): 111-130. doi: 10.1002/9780470686522.ch7.

Miao Liu, J., Q. Mei, C. Yun Xue, Z. Yuan Wang, D. Pin Li, et al. 2020. Mutation of G-protein y subunit DEP1 increases planting density and resistance to sheath blight disease in rice. Plant Biotechnology Journal: 0-2. doi: 10.1111/pbi.13500.

Nadir, S., H.B. Xiong, Q. Zhu, X.L. Zhang, H.Y. Xu, et al. 2017. Weedy rice in sustainable rice production. A review. Agronomy for Sustainable Development 37(5). doi: 10.1007/s13593-017-0456-4.

Nuñez-Muñoz, L., B. Vargas-Hernández, J. Hinojosa-Moya, R. Ruiz-Medrano, and B. Xoconostle-Cázares. 2021. Plant drought tolerance provided through genome editing of the trehalase gene. Plant Signaling and Behavior 16(4). doi: 10.1080/15592324.2021.1877005.

Oerke, E.C., and H.W. Dehne. 2004. Safeguarding production - Losses in major crops and the role of crop protection. Crop Protection 23(4): 275-285. doi: 10.1016/j.cropro.2003.10.001.

Oladosu, Y., M.Y. Rafii, N. Abdullah, G. Hussin, A. Ramli, et al. 2016. Principle and application of plant mutagenesis in crop improvement: A review. Biotechnology and Biotechnological Equipment 30(1): 1-16. doi: 10.1080/13102818.2015.1087333.

Oliva, R., C. Ji, G. Atienza-Grande, J.C. Huguet-Tapia, A. Perez-Quintero, et al. 2019. Broad-spectrum resistance to bacterial blight in rice using genome editing. Nature Biotechnology 37(11): 1344-1350. doi: 10.1038/s41587-019-0267-z.

Pan, G., X. Zhang, K. Liu, J. Zhang, X. Wu, et al. 2006. Map-based cloning of a novel rice cytochrome P450 gene CYP81A6 that confers resistance to two different classes of herbicides. Plant Molecular Biology 61(6): 933-943. doi: 10.1007/s11103-006-0058-z.

Pedroso, R.M., K. Al-Khatib, R. Alarcón-Reverte, and A.J. Fischer. 2016. A psbA mutation (Val219 to lle) causes resistance to propanil and increased susceptibility to bentazon in Cyperus difformis. Pest Management Science 72(9): 1673-1680. doi: 10.1002/ps.4267.

Qin, H., Y. Li, and R. Huang. 2020. Advances and challenges in the breeding of salt-tolerant rice. International Journal of Molecular Sciences 21(21): 1-15. doi: $10.3390 / \mathrm{ijms} 21218385$.

Qu, M., Z. Zhang, T. Liang, P. Niu, M. Wu, et al. 2021. Overexpression of a methyl-CpG-binding protein gene OsMBD707 leads to larger tiller angles and reduced photoperiod sensitivity in rice. BMC Plant Biology 21(1): 1-14. doi: 10.1186/s12870-021-02880-3.

Quibod, I.L., G. Atieza-Grande, E.G. Oreiro, D. Palmos, M.H. Nguyen, et al. 2020. The Green Revolution shaped the population structure of the rice pathogen Xanthomonas oryzae pv. oryzae. ISME Journal 14(2): 492-505. doi: 10.1038/s41396-019-0545-2.

Reddy, I.N.B.L., B.K. Kim, I.S. Yoon, K.H. Kim, and T.R. Kwon. 2017. Salt Tolerance in Rice: Focus on Mechanisms and Approaches. Rice Science 24(3): 123144. doi: 10.1016/j.rsci.2016.09.004.

Romero, F.M., and A. Gatica-Arias. 2019. CRISPR/Cas9: Development and Application in Rice Breeding. Rice Science 26(5): 265-281. doi: 10.1016/j.rsci.2019.08.001.

Saika, H., J. Horita, F. Taguchi-Shiobara, S. Nonaka, A. Nishizawa-Yokoi, et al. 2014. A novel rice cytochrome P450 gene, CYP72A31, confers tolerance to acetolactate synthase-inhibiting herbicides in rice and arabidopsis. Plant Physiology 166(3): 1232-1240. doi: 10.1104/pp.113.231266.

Sano, Y. 1984. Differential regulation of waxy gene expression in rice endosperm. Theoretical and Applied Genetics 68(5): 467-473. doi: 10.1007/BF00254822. 
Santosh Kumar, V. v., R.K. Verma, S.K. Yadav, P. Yadav, A. Watts, et al. 2020. CRISPR-Cas9 mediated genome editing of drought and salt tolerance (OsDST) gene in indica mega rice cultivar MTU1010. Physiology and Molecular Biology of Plants 26(6): 1099-1110. doi: 10.1007/s12298-020-00819-w.

Sasaki, A., N. Yamaji, K. Yokosho, and J.F. Ma. 2012. Nramp5 is a major transporter responsible for manganese and cadmium uptake in rice. Plant Cell 24(5): 2155-2167. doi: 10.1105/tpc.112.096925.

Schindele, P., F. Wolter, and H. Puchta. 2018. Transforming plant biology and breeding with CRISPR/Cas9, Cas12 and Cas13. FEBS Letters 592(12): 19541967. doi: 10.1002/1873-3468.13073.

Serrat, X., R. Esteban, N. Guibourt, L. Moysset, S. Nogués, et al. 2014. EMS mutagenesis in mature seed-derived rice calli as a new method for rapidly obtaining TILLING mutant populations. Plant Methods 10(1). doi: 10.1186/1746-4811-10-5.

Shekhawat, K., S.S. Rathore, and B.S. Chauhan. 2020. Weed management in dry direct-seeded rice: A review on challenges and opportunities for sustainable rice production. Agronomy 10(9): 1-19. doi: 10.3390/agronomy10091264.

Shen, L., Y. Hua, Y. Fu, J. Li, Q. Liu, et al. 2017. Rapid generation of genetic diversity by multiplex CRISPR/Cas9 genome editing in rice. Science China Life Sciences 60(5): 506-515. doi: 10.1007/s11427-017-9008-8.

Shufen, C., C. Yicong, F. Baobing, J. Guiai, S. Zhonghua, et al. 2019. Editing of Rice Isoamylase Gene ISA1 Provides Insights into Its Function in Starch Formation. Rice Science 26(2): 77-87. doi: 10.1016/j.rsci.2018.07.001.

Singh, V., S. Singh, H. Black, V. Boyett, S. Basu, et al. 2017. Introgression of Clearfield ${ }^{\mathrm{TM}}$ rice crop traits into weedy red rice outcrosses. Field Crops Research 207: 13-23. doi: 10.1016/j.fcr.2017.03.004.

Song, X.J., T. Kuroha, M. Ayano, T. Furuta, K. Nagai, et al. 2015. Rare allele of a previously unidentified histone H4 acetyltransferase enhances grain weight, yield, and plant biomass in rice. Proceedings of the National Academy of Sciences of the United States of America 112(1): 76-81. doi:

$10.1073 /$ pnas.1421127112.

Soriano, J.D. 1961. Mutagenic Effects of Gamma Radiation on Rice. Botanical Gazette 123(1): 57-63. http://www.jstor.org/stable/2473547.

Sripinyowanich, S., P. Klomsakul, B. Boonburapong, T. Bangyeekhun, T. Asami, et al. 2013. Exogenous ABA induces salt tolerance in indica rice (Oryza sativa L.): The role of OsP5CS1 and OsP5CR gene expression during salt stress. Environmental and Experimental Botany 86: 94-105. doi:

10.1016/j.envexpbot.2010.01.009.

Takagi, H., M. Tamiru, A. Abe, K. Yoshida, A. Uemura, et al. 2015. MutMap accelerates breeding of a salt-tolerant rice cultivar. Nature Biotechnology 33(5): 445449. doi: $10.1038 /$ nbt.3188.

Takano-Kai, N., H. Jiang, A. Powell, S. McCouch, I. Takamure, et al. 2013. Multiple and independent origins of short seeded alleles of GS3 in rice. Breeding Science 63(1): 77-85. doi: 10.1270/jsbbs.63.77.

Takasaki, H., K. Maruyama, S. Kidokoro, Y. Ito, Y. Fujita, et al. 2010. The abiotic stress-responsive NAC-type transcription factor OsNAC5 regulates stressinducible genes and stress tolerance in rice. Molecular Genetics and Genomics 284(3): 173-183. doi: 10.1007/s00438-010-0557-0.

Tanaka, N., M. Shenton, Y. Kawahara, M. Kumagai, H. Sakai, et al. 2020. Whole-Genome Sequencing of the NARO World Rice Core Collection (WRC) as the Basis for Diversity and Association Studies. Plant and Cell Physiology 61(5): 922-932. doi: 10.1093/pcp/pcaa019.

Tang, L., B. Mao, Y. Li, Q. Lv, L. Zhang, et al. 2017. Knockout of OsNramp5 using the CRISPR/Cas9 system produces low Cd-accumulating indica rice without compromising yield. Scientific Reports 7(1): 1-12. doi: 10.1038/s41598-017-14832-9.

Tang, W., J. Ye, X. Yao, P. Zhao, W. Xuan, et al. 2019. Genome-wide associated study identifies NAC42-activated nitrate transporter conferring high nitrogen use efficiency in rice. Nature Communications 10(1): 1-11. doi: 10.1038/s41467-019-13187-1.

Tian, P., J. Liu, C. Mou, C. Shi, H. Zhang, et al. 2019. GW5-Like, a homolog of GW5, negatively regulates grain width, weight and salt resistance in rice. Journal of Integrative Plant Biology 61(11): 1171-1185. doi: 10.1111/jipb.12745.

Tiwari, G.J., Q. Liu, P. Shreshtha, Z. Li, and S. Rahman. 2016. RNAi-mediated down-regulation of the expression of OsFAD2-1: Effect on lipid accumulation and expression of lipid biosynthetic genes in the rice grain. BMC Plant Biology 16(1). doi: 10.1186/s12870-016-0881-6.

Varshney, R.K., I.D. Godwin, T. Mohapatra, J.D.G. Jones, and S.R. McCouch. 2019. A SWEET solution to rice blight. Nature Biotechnology 37(11): 1280-1282. doi: 10.1038/s41587-019-0302-0.

Viana, V.E., C. Pegoraro, C. Busanello, and A. Costa de Oliveira. 2019. Mutagenesis in Rice: The Basis for Breeding a New Super Plant. Frontiers in Plant Science 10(November): 1-28. doi: 10.3389/fpls.2019.01326.

Wang, J., Z. Chen, Q. Zhang, S. Meng, and C. Wei. 2020. The NAC transcription factors OsNAC20 and OsNAC26 Regulate Starch and Storage Protein synthesis. Plant Physiology 184(4): 1775-1791. doi: 10.1104/pp.20.00984. 
Wang, W., S. Peng, H. Liu, Y. Tao, J. Huang, et al. 2017. The possibility of replacing puddled transplanted flooded rice with dry seeded rice in central China: A review. Field Crops Research 214(August): 310-320. doi: 10.1016/j.fcr.2017.09.028.

Wang, Z., X. Tian, Q. Zhao, Z. Liu, X. Li, et al. 2018a. The E3 ligase drought hypersensitive negatively regulates cuticular wax biosynthesis by promoting the degradation of transcription factor ROC4 in rice. Plant Cell 30(1): 228-244. doi: 10.1105/tpc.17.00823.

Wang, F., C. Wang, P. Liu, C. Lei, W. Hao, et al. 2016. Enhanced rice blast resistance by CRISPR/ Cas9-Targeted mutagenesis of the ERF transcription factor gene OsERF922. PLoS ONE 11(4): 1-18. doi: 10.1371/journal.pone.0154027.

Wang, J., L. Zhou, H. Shi, M. Chern, H. Yu, et al. 2018b. A single transcription factor promotes both yield and immunity in rice. Science 361(6406): 1026-1028. doi: $10.1126 /$ science.aat7675.

Wing, R.A., M.D. Purugganan, and Q. Zhang. 2018. The rice genome revolution: From an ancient grain to Green Super Rice. Nature Reviews Genetics 19(8): 505-517. doi: 10.1038/s41576-018-0024-z.

Xu, Y., Q. Lin, X. Li, F. Wang, Z. Chen, et al. 2021. Fine-tuning the amylose content of rice by precise base editing of the Wx gene. Plant Biotechnology Journal 19(1): 11-13. doi: 10.1111/pbi.13433.

Yang, G., W. Luo, J. Zhang, X. Yan, Y. Du, et al. 2019a. Genome-Wide Comparisons of Mutations Induced by Carbon-lon Beam and Gamma-Rays Irradiation in Rice via Resequencing Multiple Mutants. Frontiers in Plant Science 10(November): 1-13. doi: 10.3389/fpls.2019.01514.

Yang, L., W. Yueying, N. Jahan, H. Haitao, C. Ping, et al. 2019b. Genome-Wide Association Analysis and Allelic Mining of Grain Shape-Related Traits in Rice. Rice Science 26(6): 384-392. doi: 10.1016/j.rsci.2018.09.002.

Yin, X., A. Anand, P. Quick, and A. Bandyopadhyay. 2019. Editing a stomatal developmental gene in rice with CRISPR/Cpf1 (Yiping Qi, editor). Humana Press, New York, NY, New York.

Yin, X., A.K. Biswal, J. Dionora, K.M. Perdigon, C.P. Balahadia, et al. 2017. CRISPR-Cas9 and CRISPR-Cpf1 mediated targeting of a stomatal developmental gene EPFL9 in rice. Plant Cell Reports 36(5): 745-757. doi: 10.1007/s00299-017-2118-z.

Yu, H., T. Lin, X. Meng, H. Du, J. Zhang, et al. 2021a. A route to de novo domestication of wild allotetraploid rice. Cell 184(5): 1156-1170.e14. doi: 10.1016/j.cell.2021.01.013.

Yu, J., W. Xuan, Y. Tian, L. Fan, J. Sun, et al. 2021b. Enhanced OsNLP4-OsNiR cascade confers nitrogen use efficiency by promoting tiller number in rice. Plant Biotechnology Journal 19(1): 167-176. doi: 10.1111/pbi.13450.

Yuan, J., X. Wang, Y. Zhao, N.U. Khan, Z. Zhao, et al. 2020. Genetic basis and identification of candidate genes for salt tolerance in rice by GWAS. Scientific Reports 10(1): 1-9. doi: 10.1038/s41598-020-66604-7.

Yunyan, F., Y. Jie, W. Fangquan, F. Fangjun, L. Wenqi, et al. 2019. Production of Two Elite Glutinous Rice Varieties by Editing Wx Gene. Rice Science 26(2): 118-124. doi: 10.1016/j.rsci.2018.04.007.

Zeng, Y., J. Wen, W. Zhao, Q. Wang, and W. Huang. 2020. Rational Improvement of Rice Yield and Cold Tolerance by Editing the Three Genes OsPIN5b, GS3, and OsMYB30 With the CRISPR-Cas9 System. Frontiers in Plant Science 10(January): 1-13. doi: 10.3389/fpls.2019.01663.

Zhang, A., Y. Liu, F. Wang, T. Li, Z. Chen, et al. 2019a. Enhanced rice salinity tolerance via CRISPR/Cas9-targeted mutagenesis of the OsRR22 gene. Molecular Breeding 39(3). doi: 10.1007/s11032-019-0954-y.

Zhang, L., B. Ma, Z. Bian, X. Li, C. Zhang, et al. 2020. Grain Size Selection Using Novel Functional Markers Targeting 14 Genes in Rice. Rice 13(1): 1-16. doi: $10.1186 /$ s12284-020-00427-y.

Zhang, J., Y. Xu, X. Wu, and L. Zhu. 2002. A bentazon and sulfonylurea sensitive mutant: Breeding, genetics and potential application in seed production of hybrid rice. Theoretical and Applied Genetics 105(1): 16-22. doi: 10.1007/s00122-002-0874-8.

Zhang, C., J. Zhu, S. Chen, X. Fan, Q. Li, et al. 2019b. Wxlv, the Ancestral Allele of Rice Waxy Gene. Molecular Plant 12(8): 1157-1166. doi: 10.1016/j.molp.2019.05.011.

Zou, J., S. Zhang, W. Zhang, G. Li, Z. Chen, et al. 2006. The rice HIGH-TILLERING DWARF1 encoding an ortholog of Arabidopsis MAX3 is required for negative regulation of the outgrowth of axillary buds. Plant Journal 48(5): 687-698. doi: 10.1111/j.1365-313X.2006.02916.x.

\section{Tables}

Table 1. Rice genes and mutations involved in stress tolerance or sensitivity traits. 


\begin{tabular}{|c|c|c|c|c|c|c|}
\hline Gene & Position & Protein & $\begin{array}{l}\text { Obtained } \\
\text { mutation }\end{array}$ & Method & Trait details & Reference \\
\hline $\begin{array}{l}\text { OsRR22 } \\
\text { Os06g0183100 }\end{array}$ & Chr 6 & Q5SML5 & Knockout & CRISPR/Cas9 & $\begin{array}{l}\text { Two-component response regulator ORR22. } \\
\text { Salt tolerance } 0.75 \% \mathrm{NaCl} \text {. }\end{array}$ & $\begin{array}{l}\text { (Zhang et al., } \\
\text { 2019a) }\end{array}$ \\
\hline $\begin{array}{l}\text { STL1 } \\
\text { Os04g0110600 } \\
\text { Salt tolerance Level 1, } \\
\text { Stress repressive zinc } \\
\text { finger protein } 4\end{array}$ & Chr 4 & Q7XXF2 & SNP & None & $\begin{array}{l}\text { hap1 tolerance } 0.9 \% \text { salt, the gene is the } \\
\text { homolog of Arabidopsis salt tolerance gene } \\
\text { SRP1 (Stress associated RNA-binding protein } \\
\text { 1, AT2G17975). Knock-out mutation in the } \\
\text { srp1 allele reduced sensitivity to ABA and salt } \\
\text { stress. }\end{array}$ & $\begin{array}{l}\text { (Yuan et al., } \\
2020)\end{array}$ \\
\hline $\begin{array}{l}\text { MSL37 } \\
\text { Os11g0163500 } \\
\text { OsGTgamma-2 }\end{array}$ & Chr 11 & Q53PP7 & $\begin{array}{l}\text { Natural } \\
\text { variability- } \\
\text { Knockout }\end{array}$ & $\begin{array}{l}\text { Spontaneous } \\
\text { mutation- } \\
\text { CRISPR/Cas } 9\end{array}$ & Knock-out results in salt sensitivity. & $\begin{array}{l}\text { (Liu et al., } \\
2020 d)\end{array}$ \\
\hline $\begin{array}{l}\text { Os03g0786400 OsDST, } \\
\text { DLN102, OsDLN102, } \\
\text { Negative regulation of } \\
\text { response to salt stress }\end{array}$ & Chr 3 & Q10CE2 & Knockdown & $\begin{array}{l}\text { Mutant/ } \\
\text { CRISPR/Cas9 }\end{array}$ & $\begin{array}{l}\text { Knockdown improved the tolerance to stress, } \\
\text { as also observed in the dst mutant. } \mathrm{C} 2 \mathrm{H} 2 \text { zinc } \\
\text { finger transcription factor, drought and salt } \\
\text { tolerance, stomatal aperture control }\end{array}$ & $\begin{array}{l}\text { (Cui et al., 2015; } \\
\text { Santosh Kumar } \\
\text { et al., 2020) }\end{array}$ \\
\hline $\begin{array}{l}\text { P5C } \\
\text { Os05g0455500 }\end{array}$ & Chr 5 & 004226 & $\begin{array}{l}\text { Natural: } \\
\text { cultivar LPT123 } \\
\text { is salt- } \\
\text { susceptible } \\
\text { versus salt- } \\
\text { tolerant line } \\
\text { LPT123-TC171 }\end{array}$ & None & $\begin{array}{l}\text { The enzyme increases the proline } \\
\text { accumulation and salt resistance mediated by } \\
\text { ABA application. }\end{array}$ & $\begin{array}{l}\text { (Sripinyowanich } \\
\text { et al., 2013) }\end{array}$ \\
\hline $\begin{array}{l}\text { SKC1 } \\
\text { Os01g0307500 } \\
\text { OsHKT1;5, } \\
\text { OsHKT8 }\end{array}$ & Chr 1 & Q0JNB6 & Wild relatives & None & $\begin{array}{l}\text { Variant V395 (is salt tolerant), while L395 is } \\
\text { sensitive. }\end{array}$ & $\begin{array}{l}\text { (Jayabalan et } \\
\text { al., 2019) }\end{array}$ \\
\hline $\begin{array}{l}\text { Os10g0521000 } \\
\text { Based on Z.mays } \\
\text { GRMZM2G162690 and } \\
\text { A. thaliana AT4G24040 }\end{array}$ & Chr 10 & Q9FWC1 & $\begin{array}{l}\text { Substitution } \\
\text { S163T }\end{array}$ & CRISPR/Cas9 & $\begin{array}{l}\text { Mutation of domain WDS to replicate } \\
\text { Selaginella moellendoffii WDT. The enzyme } \\
\text { may be less efficient in allowing the } \\
\text { accumulation of trehalose. }\end{array}$ & $\begin{array}{l}\text { (Nuñez-Muñoz } \\
\text { et al., 2021) }\end{array}$ \\
\hline $\begin{array}{l}\text { OsEPFL9 } \\
\text { Os01g0824500 } \\
\text { Epidermal Patterning } \\
\text { Factor Like-9 }\end{array}$ & Chr 1 & Q5JN76 & Knockout & CRISPR/Cpf1 & $\begin{array}{l}\text { Increased water use efficiency under stress } \\
\text { because of reduced stomatal count }\end{array}$ & $\begin{array}{l}\text { (Yin et al., 2017, } \\
\text { 2019) }\end{array}$ \\
\hline $\begin{array}{l}\text { DHS } \\
\text { Os02g0682300 } \\
\text { Drought hypersensitive }\end{array}$ & Chr 2 & Q6EU38 & $\begin{array}{l}\text { Knockout- } \\
\text { Overexpression }\end{array}$ & $\begin{array}{l}\text { CRISPR/Cas9- } \\
\text { gene transfer }\end{array}$ & $\begin{array}{l}\text { Knockout results in more cuticular wax. } \\
\text { Overexpression (DHS OE) plantlets grew more } \\
\text { slowly. The enzyme is a ubiquitin that } \\
\text { degrades ROC4 that positively regulates } \\
\text { cuticular wax biosynthesis }\end{array}$ & $\begin{array}{l}\text { (Wang et al., } \\
\text { 2018a) }\end{array}$ \\
\hline $\begin{array}{l}\text { RCS1 } \\
\text { Os12g0625000 }\end{array}$ & Chr 12 & Q9XEA6 & S189N & EMS & $\begin{array}{l}\text { Tolerates } 20 \mu \mathrm{M} \text { As }(\mathrm{III}) \text {. The mutation } \\
\text { increases As tolerance/decreased } \\
\text { accumulation in the grain/increase Se } \\
\text { accumulation in the grain. }\end{array}$ & $\begin{array}{l}\text { (Sun et al., } \\
\text { 2021) }\end{array}$ \\
\hline $\begin{array}{l}\text { O-acetylserine (thiol) } \\
\text { lyase, Cysteine } \\
\text { synthase. arsenite } \\
\text { tolerant } 1\end{array}$ & & & & & & \\
\hline $\begin{array}{l}\text { OsNramp5 } \\
\text { Os07g0257200 } \\
\text { Manganese and } \\
\text { Cadmium transporter, } \\
\text { Mn and Cd uptake, }\end{array}$ & Chr 7 & $\begin{array}{l}\text { Q8H4H5 } \\
\text { I7GYG6 }\end{array}$ & Knockout & CRISPR/Cas9 & Low Cd accumulation & $\begin{array}{l}\text { (Sasaki et al., } \\
\text { 2012; Tang et } \\
\text { al., 2017; Chang } \\
\text { et al., 2020) }\end{array}$ \\
\hline
\end{tabular}




\begin{tabular}{|c|c|c|c|c|c|c|}
\hline $\begin{array}{l}\text { OsNramp1 } \\
\text { Os07g0258400 } \\
\text { Metal transporter }\end{array}$ & Chr 7 & Q0D7E4 & Knockout & CRISPR/Cas9 & $\begin{array}{l}\text { Low Cd accumulation. It works as a plasma } \\
\text { membrane-localized transporter/uptake for } \\
\text { Mn and Cd; it is complementary to } \\
\text { OsNRAMP5 in the uptake of Mn and Cd. }\end{array}$ & $\begin{array}{l}\text { (Chang et al., } \\
\text { 2020) }\end{array}$ \\
\hline $\begin{array}{l}\text { OsNTL3 } \\
\text { Os01g0261200 } \\
\text { Thermotolerance }\end{array}$ & Chr 1 & Q7GCL7 & $\begin{array}{l}\text { Natural } \\
\text { variability- }\end{array}$ & None & $\begin{array}{l}\text { OsNTL3 is required for heat stress tolerance in } \\
\text { rice. Loss-of-function mutation of OsNTL3 } \\
\text { confers heat sensitivity. It regulates the } \\
\text { expression of genes involved in ER protein } \\
\text { folding. }\end{array}$ & $\begin{array}{l}\text { (Liu et al., } \\
2020 \text { a) }\end{array}$ \\
\hline $\begin{array}{l}\text { OsMYB30 } \\
\text { Os02g0624300, }\end{array}$ & Chr 2 & Q6K1S6 & Knockout & CRISPR/Cas9 & $\begin{array}{l}\text { The protein OsMYB } 30 \text { is a nuclear protein that } \\
\text { acts as a negative regulator of cold tolerance. } \\
\text { Mutant shows increased cold tolerance. }\end{array}$ & $\begin{array}{l}\text { (Zeng et al., } \\
2020 \text { ) }\end{array}$ \\
\hline Cold tolerance gene & & & & & & \\
\hline
\end{tabular}

Table 2. Rice genes and mutations in herbicide resistance traits. 


\begin{tabular}{|c|c|c|c|c|c|c|}
\hline Gene $(*)$ & Position & Protein & $\begin{array}{l}\text { Obtained } \\
\text { mutation }\end{array}$ & Method & Trait details & References \\
\hline $\begin{array}{l}\text { OsTubA2 } \\
\text { Os11g0247300 }\end{array}$ & Chr 11 & Q53M51 & M268T & $\begin{array}{l}\text { CRISPR/Cas9- } \\
\text { Base editor }\end{array}$ & $\begin{array}{l}\text { In vitro trifluralin } 4 \mathrm{mg} / \text {, pendimethaline } 6.6 \\
\mathrm{mg} / \mathrm{L}\end{array}$ & $\begin{array}{l}\text { L. Liu et al., } \\
\text { 2021) }\end{array}$ \\
\hline \multirow{8}{*}{$\begin{array}{l}\text { ACCase2 } \\
\text { Os05g0295300 }\end{array}$} & \multirow[t]{8}{*}{ Chr 5} & \multirow[t]{8}{*}{ B9FK36 } & W2027C & $\begin{array}{l}\text { Seeds-Gamma } \\
\text { Rays 280Gy }\end{array}$ & $\begin{array}{l}\text { quizalofop-p-ethyl = } 75 \mathrm{~g} / \mathrm{ha} \text {; haloxyfop-p- } \\
\text { methyl = } 62.35 \mathrm{~g} / \mathrm{ha}\end{array}$ & $\begin{array}{l}\text { (de Andrade et } \\
\text { al., 2018) }\end{array}$ \\
\hline & & & I1879V & \multirow{2}{*}{$\begin{array}{l}\text { CRISPR/Cas9- } \\
\text { Base editor }\end{array}$} & \multirow[t]{2}{*}{ haloxyfop-R-methyl, 1 and $2 \mu \mathrm{M}$ in vitro. } & \multirow{2}{*}{$\begin{array}{l}\text { (Liu et al., } \\
2020 \mathrm{~b} ; \mathrm{c})\end{array}$} \\
\hline & & & W2125S & & & \\
\hline & & & I1781L & $\begin{array}{l}\text { Tissue culture } \\
\text { mutation }\end{array}$ & quizalofop-p-ethyl=235 g ai ha-1 & $\begin{array}{l}\text { (Camacho et } \\
\text { al., 2019) }\end{array}$ \\
\hline & & & D2176G & \multirow{2}{*}{$\begin{array}{l}\text { CRISPR-Prime } \\
\text { Editing }\end{array}$} & \multirow[t]{2}{*}{ Herbicide resistance } & \multirow{2}{*}{$\begin{array}{l}\text { (Xu et al., } \\
2020)\end{array}$} \\
\hline & & & G2201A & & & \\
\hline & & & C2186R & $\begin{array}{l}\text { CRISPR-Base } \\
\text { editor }\end{array}$ & Herbicide resistance & $\begin{array}{l}\text { (Li et al., 2018; } \\
\text { Liu et al., } \\
\text { 2020c) }\end{array}$ \\
\hline & & & $\begin{array}{l}\text { P1927F, } \\
\text { W2125C, } \\
\text { S1866F and } \\
\text { A1884P }\end{array}$ & $\begin{array}{l}\text { CRISPR-Base } \\
\text { editor }\end{array}$ & $\begin{array}{l}\text { Herbicide resistance } 34 \mathrm{~g} / \mathrm{Ha} \text {. High tolerance } \\
\text { P1927F, W2125C versus low tolerance } \\
\text { S1866F and A1884P }\end{array}$ & $\begin{array}{l}\text { (Li et al., } \\
2020 \mathrm{~b} \text {; Liu et } \\
\text { al., 2020c) }\end{array}$ \\
\hline $\begin{array}{l}\text { psbAAAS46167 } \\
\text { (Photosystem II } \\
\text { protein D1, } \\
\text { psbA) }\end{array}$ & Chloroplast & P0C434 & S264G & $\begin{array}{l}\text { Wild radish, } \\
\text { Spontaneous } \\
\text { mutation- }\end{array}$ & $\begin{array}{l}\text { Atrazine }>50 \text {-fold ( } 4000(187 \mathrm{~g} \text { a.i. ha- } 1 \\
\text { atrazine), (S) Bromoxynil }\end{array}$ & $\begin{array}{l}\text { (Lu et al., } \\
2019)\end{array}$ \\
\hline $\begin{array}{l}\text { HPPD } \\
\text { Os02g0280700 } \\
\text { Inhibitor } \\
\text { Sensitive } 1\end{array}$ & Chr 2 & $\begin{array}{l}\mathrm{Fe}(\mathrm{II}) / 2- \\
\text { oxoglutarate- } \\
\text { dependent } \\
\text { oxygenase }\end{array}$ & $\begin{array}{l}\text { 28-bp deletion } \\
\text { allele (his1). }\end{array}$ & $\begin{array}{l}\text { wild } \\
\text { Nipponbare } \\
\text { lacked deletion } \\
\text { (HIS1) }\end{array}$ & $\begin{array}{l}\text { b-Triketone herbicides, HIS1detoxifies b- } \\
\text { triketone herbicides by hydroxylation. }\end{array}$ & $\begin{array}{l}\text { (Maeda et al., } \\
\text { 2019) }\end{array}$ \\
\hline$A H A S, A L S$ & \multirow[t]{15}{*}{ Chr 2} & \multirow[t]{19}{*}{ Q6K2E8 } & W548L & \multirow{3}{*}{$\begin{array}{l}\text { CRISPR-Prime } \\
\text { Editing }\end{array}$} & \multirow[t]{3}{*}{ Herbicide tolerance } & \multirow{3}{*}{$\begin{array}{l}\text { (Lin et al., } \\
\text { 2020; Xu et al., } \\
\text { 2020) }\end{array}$} \\
\hline Os02g0510200 & & & P171S & & & \\
\hline \multirow{17}{*}{$\begin{array}{l}\text { Acetohydroxy } \\
\text { acid synthase }\end{array}$} & & & & & & \\
\hline & & & A96V & \multirow{2}{*}{$\begin{array}{l}\text { CRISPR/Cas } 9 \\
\text { Base editor }\end{array}$} & \multirow[t]{2}{*}{ Imazamox (quantity not reported) } & \multirow{2}{*}{$\begin{array}{l}\text { (Shimatani et } \\
\text { al., 2017) }\end{array}$} \\
\hline & & & $(\mathrm{C} 287 \mathrm{~T})$ & & & \\
\hline & & & G654E & $\begin{array}{l}\text { Chemical } \\
\text { mutation }\end{array}$ & Clearfield 121 & $\begin{array}{l}\text { (Singh et al., } \\
\text { 2017: Bzour et }\end{array}$ \\
\hline & & & & & Clearfield 141 & al., 2018) \\
\hline & & & & & IRGA422 & \\
\hline & & & S653N & $\begin{array}{l}\text { Chemical } \\
\text { mutation }\end{array}$ & $\begin{array}{l}\text { Named CL161 and CLXL8 increased } \\
\text { herbicide tolerance }\end{array}$ & $\begin{array}{l}\text { (Singh et al., } \\
\text { 2017) }\end{array}$ \\
\hline & & & $\begin{array}{l}\text { W548L or } \\
\text { P171S }\end{array}$ & $\begin{array}{l}\text { Recombinant } \\
\text { protein }\end{array}$ & Herbicide tolerance & $\begin{array}{l}\text { (Kawai et al., } \\
\text { 2008) }\end{array}$ \\
\hline & & & W548 & $\begin{array}{l}\text { CRISPR-Prime } \\
\text { Editing }\end{array}$ & Herbicide tolerance & $\begin{array}{l}\text { (Xu et al., } \\
2020 \text { ) }\end{array}$ \\
\hline & & & E549 & & & \\
\hline & & & $\mathrm{A} 122 \mathrm{~T}$ & Sodium Azide & IMINTA1, IMINTA4 & $\begin{array}{l}\text { (Sagare et al., } \\
\text { 2020) }\end{array}$ \\
\hline & & & W548L & CRISPR & Herbicide tolerance & $\begin{array}{l}\text { (Sun et al., } \\
2016 \text { ) }\end{array}$ \\
\hline & & & S627I & & & \\
\hline & Arabidopsis & & P171H/W548L & Recombinant & $100 \mathrm{mM}$ IQ & $\begin{array}{l}\text { (Kawai et al., } \\
2008 \text { ) }\end{array}$ \\
\hline & Modeling & & W574L & & 100 mM CS/BM/IQ/IP/PS & \\
\hline & & & P197S & & 100 mM BM & \\
\hline & & & S653I & & $100 \mathrm{mM}$ IP & \\
\hline OsEPSPS & Chr 6 & A0A0N7KLH2 & T169l & CRISPR-Prime & NA & (Li et al., \\
\hline
\end{tabular}

Page 14/23 
$(S)=$ Susceptible, genomic

${ }^{\star}{ }^{\star}$ Additional information at The Rice Annotation Project (RAP). (Jiang et al., 2013; Oliva et al., 2019; Varshney et al., 2019).

CS, chlorsulfuron; BM, bensulfuron-methyl; IQ, imazaquin; IP, imazapyr; PM, pyriminobac; PS, pyrithiobac-sodium; BS, bispyribac- sodium.

Table 3. Rice genes and mutations with pathogen-resistant traits.

\begin{tabular}{|c|c|c|c|c|c|c|}
\hline Gene & Position & Protein & $\begin{array}{l}\text { Obtained } \\
\text { Mutation }\end{array}$ & Method & Trait details & Reference \\
\hline $\begin{array}{l}\text { Os11g0508600 } \\
\text { Sweet } 14\end{array}$ & Chr 11 & Q2R3P9 & Knockout & $\begin{array}{l}\text { CRISPR- } \\
\text { Cas9 }\end{array}$ & $\begin{array}{l}\text { Xanthomonas oryzae pv. Oryzae resistance, } \\
\text { probably by avoiding sugar access for the } \\
\text { pathogen growth, or by not reducing copper } \\
\text { in the xylem }\end{array}$ & $\begin{array}{l}\text { (Jiang et al., } \\
\text { 2013; Oliva et al., } \\
\text { 2019; Varshney } \\
\text { et al., 2019) }\end{array}$ \\
\hline $\begin{array}{l}\text { Os08g0535200 } \\
\text { Sweet11 }\end{array}$ & Chr 8 & Q6YZF3 & Knockout & $\begin{array}{l}\text { CRISPR- } \\
\text { Cas9 }\end{array}$ & $\begin{array}{l}\text { Xanthomonas oryzae pv. Oryzae resistance, } \\
\text { probably by avoiding sugar access for the } \\
\text { pathogen growth, or by not reducing copper } \\
\text { in the xylem }\end{array}$ & $\begin{array}{l}\text { (Oliva et al., } \\
\text { 2019; Varshney } \\
\text { et al., 2019) }\end{array}$ \\
\hline $\begin{array}{l}\text { Os12g0476200 } \\
\text { Sweet13 }\end{array}$ & Chr 12 & Q2QR07 & Knockout & $\begin{array}{l}\text { CRISPR- } \\
\text { Cas9 }\end{array}$ & $\begin{array}{l}\text { Xanthomonas oryzae pv. Oryzae resistance, } \\
\text { probably by avoiding sugar access for the } \\
\text { pathogen growth, or by not reducing copper } \\
\text { in the xylem }\end{array}$ & $\begin{array}{l}\text { (Oliva et al., } \\
\text { 2019; Varshney } \\
\text { et al., 2019) }\end{array}$ \\
\hline $\begin{array}{l}\text { Os07g0555200 } \\
\text { translation initiation factor } 4 \\
\text { gamma gene (elF4G) }\end{array}$ & Chr 7 & B9FXV5 & $\begin{array}{l}\text { Knockout and } \\
\text { mutations on } \\
\text { SVLFPNLAGKS }\end{array}$ & $\begin{array}{l}\text { CRISPR- } \\
\text { Cas9 }\end{array}$ & $\begin{array}{l}\text { Resistance to rice tungro spherical virus } \\
\text { (RTSV) }\end{array}$ & $\begin{array}{l}\text { (Macovei et al., } \\
\text { 2018) }\end{array}$ \\
\hline $\begin{array}{l}\text { Os01g0752500, ethylene } \\
\text { response factor } 922 \\
\text { OsERF922, } \\
\text { LOC_Os01g54890.1 }\end{array}$ & Chr 1 & Q5JMX7 & Knockout & CRISPR & Magnaporthe oryzae, Blast resistance & $\begin{array}{l}\text { (Wang et al., } \\
\text { 2016) }\end{array}$ \\
\hline
\end{tabular}

Table 4. Rice genes and mutations involved in grain quality, quantity, weight, and plant structural traits. 


\begin{tabular}{|c|c|c|c|c|c|c|}
\hline Gene & Position & Protein & $\begin{array}{l}\text { Obtained } \\
\text { mutation }\end{array}$ & Method & Trait details & Reference \\
\hline $\begin{array}{l}\text { OsDEP1 } \\
\text { Os09g0441900 }\end{array}$ & Chr 2 & Q67UU9 & $\begin{array}{l}\text { Mutation, } \\
\text { promoter }\end{array}$ & $\begin{array}{l}\text { Spontaneous } \\
\text { mutation - } \\
\text { CRISPR / Cas9 }\end{array}$ & $\begin{array}{l}\text { More expression, yield increase } 15 \% \text {. The interaction } \\
\text { between DEP1 and LPA1 suppresses } \\
\text { PIN1a expression, leading to an increase in planting } \\
\text { density. The panicle number per plant was the main } \\
\text { contributor to the increase in grains per rice plant in } \\
\text { the DEP1 mutants. }\end{array}$ & $\begin{array}{l}\text { (Huang et } \\
\text { al., 2018; } \\
\text { Fu et al., } \\
2019 ; \\
\text { Miao Liu } \\
\text { et al., } \\
\text { 2020) }\end{array}$ \\
\hline $\begin{array}{l}\text { Gn1a } \\
\text { Os01g0197700 } \\
\text { OsCKX2 }\end{array}$ & Chr 1 & Q4ADV8 & Knockout & CRISPR/Cas9 & $\begin{array}{l}\text { Catalyzes the oxidation of cytokinin, enhanced the } \\
\text { grain yield by increasing the grain number per } \\
\text { panicle. Twice flowering relative to the wild type. }\end{array}$ & $\begin{array}{l}\text { (Li et al., } \\
\text { 2016a; } \\
\text { Shen et } \\
\text { al., 2017; } \\
\text { Huang et } \\
\text { al., 2018) }\end{array}$ \\
\hline $\begin{array}{l}\text { GS3 } \\
\text { Os03g0407400 }\end{array}$ & Chr 3 & C6L686 & Knockout & $\begin{array}{l}\text { CRISPR/Cas9 - } \\
\text { Spontaneous } \\
\text { mutation }\end{array}$ & $\begin{array}{l}\delta \text { subunit of } G \text { protein. Regulator of grain size and } \\
\text { organ size. Produces a longer grain length. Knockout } \\
\text { and deletions produce short seeds, such as } 320 \text { bp } \\
\text { and } 13 \text { bp deletions in the fifth exon of GS } 3 \text { that } \\
\text { occurred in a japonica-like ancestor. The } 4 \text { bp and } 1 \\
+3 \text { bp deletions occurred in an indica-like ancestor. } \\
\text { Farmers and early breeders imposed artificial } \\
\text { selection favoring short seeds }\end{array}$ & $\begin{array}{l}\text { (Takano- } \\
\text { Kai et al., } \\
2013 ; \\
\text { Shen et } \\
\text { al., 2017; } \\
\text { Yang et } \\
\text { al., } \\
\text { 2019b) }\end{array}$ \\
\hline $\begin{array}{l}\text { IPA1 } \\
\text { Os08g0509600 } \\
\text { Transcription } \\
\text { factor Ideal Plant } \\
\text { Architecture } 1\end{array}$ & Chr 8 & Q7EXZ2 & Knockout & CRISPR/Cas9 & $\begin{array}{l}\text { Squamosa promoter-binding-like protein } 14 \text {. Specific } \\
\text { mutations between bases } 854 \text { to } 876 \text { result in more } \\
\text { protein and produce less tillering, more grains and a } \\
\text { higher frequency of seed set. It reduces unproductive } \\
\text { tillers and increases the number of grains per } \\
\text { panicle, while higher IPA1 levels enhance immunity. }\end{array}$ & $\begin{array}{l}\text { (Li et al., } \\
2016 a ; \\
\text { Wang et } \\
\text { al., } \\
\text { 2018b) }\end{array}$ \\
\hline $\begin{array}{l}\text { WX1 } \\
\text { Os06g0133000 } \\
\text { granule-bound } \\
\text { starch synthase I } \\
\text { GBSSI, OsGBSS1, } \\
\text { waxy }\end{array}$ & Chr 6 & Q0DEV5 & $\begin{array}{l}\text { Knockout, } \\
\text { mutations }\end{array}$ & $\begin{array}{l}\text { CRISPR/Cas9 } \\
\text { P124F, R125W } \\
\text { T178I, T178S, } \\
\text { R158H, Y191H, } \\
\text { R158H, G159A, } \\
\text { D161N, } \\
\text { G159K, G159A, } \\
\text { G159E, V160F, } \\
\text { S415P }\end{array}$ & $\begin{array}{l}\text { Modulate the synthesis of amylose in the } \\
\text { endosperm. Amylose contents change the } \\
\text { appearance of the rice endosperm }>12 \% \text { results in } \\
\text { transparent endosperm/semitranslucent }(8-12 \%) / \text { or } \\
\text { opaque }(<8 \%) \text {. Favorable rice palatability usually } \\
\text { requires low to intermediate AC }(10-20 \%) \text {. The null } \\
\text { wax results in an absence of amylose, resulting in } \\
\text { starch granules with } 100 \% \text { amylopectin production, } \\
\text { referred to as waxy or glutenous starch. S415P } \\
\text { changes phosphorylation, resulting in moderate } \\
\text { enzyme activity and a content of amylose. }\end{array}$ & $\begin{array}{l}\text { (Sano, } \\
\text { 1984; } \\
\text { Yunyan } \\
\text { et al., } \\
2019 ; \\
\text { Zhang et } \\
\text { al.,' } \\
\text { 2019b; } \\
\text { Huang et } \\
\text { al., 2020; } \\
\text { Xu et al., } \\
\text { 2021) }\end{array}$ \\
\hline $\begin{array}{l}\text { ISA1 } \\
\text { Os08g0520900 } \\
\text { isoamylase } 1\end{array}$ & Chr 8 & DOTZFO & Knockout & CRISPR/Cas9 & $\begin{array}{l}\text { Decreased endosperm contents of total starch, } \\
\text { amylose and amylopectin. Increased soluble sugar } \\
\text { content and starch gel consistency. }\end{array}$ & $\begin{array}{l}\text { (Shufen } \\
\text { et al., } \\
2019 \text { ) }\end{array}$ \\
\hline $\begin{array}{l}\text { OsNAC20 } \\
\text { Os01g0104500 } \\
\text { OsNAC26 } \\
\text { Os01g0393100 }\end{array}$ & Chr 1 & $\begin{array}{l}\text { Q9FTY0 } \\
\text { (OsNAC20) } \\
\text { Q5VNK1 } \\
\text { (OsNAC26) }\end{array}$ & Knockout & CRISPR/Cas9 & $\begin{array}{l}\text { Double knockout osnac20/26 displayed a floury } \\
\text { grain caused by decreased starch and storage } \\
\text { protein content. Both proteins transactivate the } \\
\text { expression of SSI, Pul, GluA1, GluB4/5, a-globulin } \\
\text { and } 16 \mathrm{kD} \text { prolamin and indirectly influence DPE1 } \\
\text { expression to regulate starch and storage protein } \\
\text { synthesis. }\end{array}$ & $\begin{array}{l}\text { (Wang et } \\
\text { al., 2020) }\end{array}$ \\
\hline $\begin{array}{l}\text { GW5 } \\
\text { Os05g0187500 } \\
\text { Grain Size on } \\
\text { Chromosome 5, } \\
\text { qSW5/GW5, } \\
\text { GSE5 }\end{array}$ & Chr 5 & $\begin{array}{l}\text { Q75KY5 } \\
\text { A0A1D8GZC0 }\end{array}$ & Knockout & $\begin{array}{l}\text { Spontaneous } \\
\text { mutation }\end{array}$ & $\begin{array}{l}\text { GW5 could function as a key regulator to coordinate } \\
\text { the performance of the other grain size genes. gw5 } \\
\text { contributes to an increased grain width and weight. } \\
\text { Positive regulator of brassinosteroid signaling. }\end{array}$ & $\begin{array}{l}\text { (Zhang et } \\
\text { al., 2020) }\end{array}$ \\
\hline $\begin{array}{l}\text { GW5L } \\
\text { Os01g0190500 } \\
\text { GW5L } \\
\text { homologue of } \\
\text { GW5 }\end{array}$ & Chr 1 & B8ADP5 & Knockout & $\begin{array}{l}\text { Spontaneous } \\
\text { mutation }\end{array}$ & $\begin{array}{l}\text { Knockout results in shorter and wider grains. } \\
\text { Overexpression could confer salt stress resistance } \\
\text { through an association with calmodulin protein } \\
\text { OsCaM1-1. }\end{array}$ & $\begin{array}{l}\text { (Tian et } \\
\text { al., 2019) }\end{array}$ \\
\hline $\begin{array}{l}\text { GW6a } \\
\text { Os06g0650300 }\end{array}$ & Chr 6 & Q67UR2 & Over expression & $\begin{array}{l}\text { Spontaneous } \\
\text { mutation }\end{array}$ & $\begin{array}{l}\text { Histone } \mathrm{H} 4 \text { acetyltransferase, regulation of grain } \\
\text { weight, yield, and plant biomass. Elevated OsglHAT1 }\end{array}$ & $\begin{array}{l}\text { (Song et } \\
\text { al., 2015; }\end{array}$ \\
\hline
\end{tabular}

Page 16/23 
chromosome 6

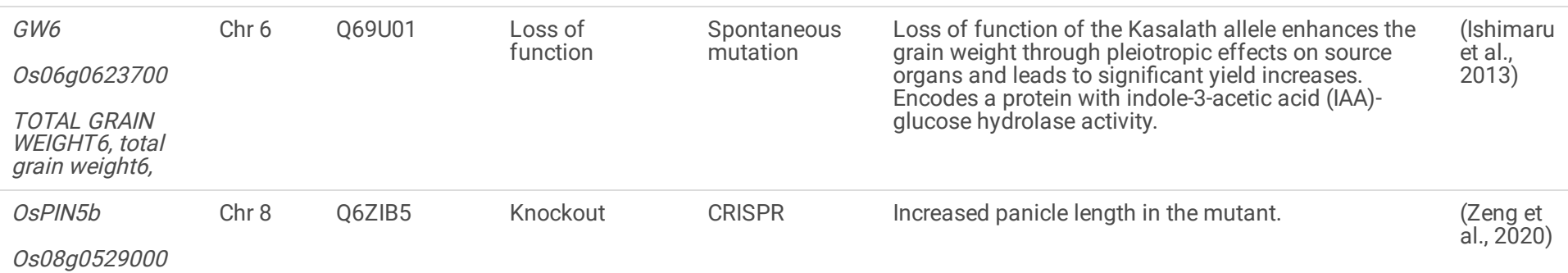

a panicle length

gene

$H d 1 / S E 1$

$\begin{array}{lll}\text { Chr } 6 & \text { Q9FDX8 } & \text { Knockout }\end{array}$

CRISPR-Cas9/

Zinc finger protein, Heading date. Under long day

(Shen et

Os06g0275000

Spontaneous

conditions suppresses HD $3 A$,
the suppression of flowering.

al., 2017;

Tanaka et

al., 2020)

\begin{tabular}{|c|c|c|c|c|c|c|}
\hline $\begin{array}{l}\text { HTD1 } \\
\text { Os04g0550600 } \\
\text { High-Tillering } \\
\text { Dwarf } 1\end{array}$ & Chr 4 & Q7XU29 & $\begin{array}{l}\text { Loss of } \\
\text { function }\end{array}$ & $\begin{array}{l}\text { Spontaneous } \\
\text { mutation/ } \\
\text { CRISPR }\end{array}$ & $\begin{array}{l}\text { Landraces contain HTD1, while domesticated rice } \\
\text { have } h t d 1 \text {. The defect in HTD1 is responsible for } \\
\text { both high-tillering and dwarf phenotypes in the htd1 } \\
\text { mutant. Auxin induces HTD1 expression. The protein } \\
\text { negatively regulates the outgrowth of axillary buds } \\
\text { and is related to strigolactones biosynthesis }\end{array}$ & $\begin{array}{l}\text { (Zou et } \\
\text { al., 2006; } \\
\text { Lacchini } \\
\text { et al., } \\
\text { 2020) }\end{array}$ \\
\hline $\begin{array}{l}\text { LPA1 } \\
\text { Os03g0237250 } \\
\text { Loose Plant } \\
\text { Architecture1 }\end{array}$ & Chr 3 & L7PBL4 & $\begin{array}{l}\text { Overexpression/ } \\
\text { Knockout }\end{array}$ & $\begin{array}{l}\text { Spontaneous } \\
\text { mutation }\end{array}$ & $\begin{array}{l}\text { Plant architecture. Related to lamina inclination by } \\
\text { suppressing auxin signaling. LPA1 is an active } \\
\text { transcriptional repressor. Negatively controls the tiller } \\
\text { and lamina joint angle in an expression level- } \\
\text { dependent manner. LPA1 overexpressors contain } \\
\text { higher levels of IAA, increases planting density and } \\
\text { resistance to sheath blight disease via activation of } \\
\text { PIN-FORMED 1a. Exaggerated lamina angles } \\
\text { observed in knockout mutants (Ipa1). Ipa1 mutants } \\
\text { might exhibit less efficient auxin flux. }\end{array}$ & $\begin{array}{l}\text { (Liu et al., } \\
2016 a)\end{array}$ \\
\hline $\begin{array}{l}\text { OsMeCP } \\
\text { Os12g0620400 } \\
\text { methyl-CpG }\end{array}$ & Chr 12 & QOILV0 & $\begin{array}{l}\text { Overexpression/ } \\
\text { RNAi/ CRISPR } \\
\text { Knockout }\end{array}$ & $\begin{array}{l}\text { CRISPR/Cas9 } \\
\text { knockout,Gene } \\
\text { transfer } \\
\text { overexpression } \\
\text { and RNAi }\end{array}$ & $\begin{array}{l}\text { Overexpression of OsMBD707 results in larger tiller } \\
\text { angles and reduced photoperiod sensitivity. }\end{array}$ & $\begin{array}{l}\text { (Qu et al., } \\
2021)\end{array}$ \\
\hline
\end{tabular}

binding domain

protein, Methyl-

CpG binding

domain

containing

protein

\begin{tabular}{|c|c|c|c|c|c|c|}
\hline $\begin{array}{l}\text { Hd2 } \\
\text { Os07g0695100 }\end{array}$ & Chr 7 & Q0D3B6 & $\begin{array}{l}\text { 2-8bp deletion } \\
\text { in } \mathrm{Hd} 2\end{array}$ & $\begin{array}{l}\text { Hap_3 and } \\
\text { Hap_6 } \\
\text { mutants }\end{array}$ & $\begin{array}{l}\text { Early flowering/low photosensitivity. Plants can be } \\
\text { planted at any time of year }\end{array}$ & $\begin{array}{l}\text { (Gao et } \\
\text { al., 2014) }\end{array}$ \\
\hline
\end{tabular}

Heading date 2

\begin{tabular}{|c|c|c|c|c|c|c|}
\hline $\begin{array}{l}\text { Ep3 } \\
\text { Os02g0260200 } \\
\text { ERECT PANICLE } \\
3,\end{array}$ & Chr 2 & G3CKN6 & $\begin{array}{l}\text { Mutation } \\
\text { (knockout, } \\
\text { recesive) }\end{array}$ & $\begin{array}{l}\text { 60Co } \\
\text { Irradiated } \\
\text { japonica } \\
\text { cultivar } \\
\text { Zhonghua 11, } \\
\text { CRISPR/Cas9 } \\
\text { knockout }\end{array}$ & $\begin{array}{l}\text { Increased panicle size. Mutants modulate cytokinin } \\
\text { level in plant tissues by down regulating cytokinin } \\
\text { oxidase /dehydrogenase }\end{array}$ & $\begin{array}{l}\text { (Li et al., } \\
\text { 2011a; } \\
\text { Shen et } \\
\text { al., 2017) }\end{array}$ \\
\hline $\begin{array}{l}\text { Se5 } \\
\text { Os06g0603000 }\end{array}$ & \multirow[t]{2}{*}{ Chr 6} & \multirow[t]{2}{*}{ Q69XJ4 } & \multirow[t]{2}{*}{ Gamma rays } & \multirow[t]{2}{*}{ s73 mutant } & \multirow[t]{2}{*}{$\begin{array}{l}\text { Identified in a gamma-irradiated Bahia collection, } \\
\text { displays early flowering and photoperiodic } \\
\text { insensitivity due to a null mutation. }\end{array}$} & \multirow[t]{2}{*}{$\begin{array}{l}\text { (Andrés } \\
\text { et al., } \\
2009 \text { ) }\end{array}$} \\
\hline Photosensitivity5 & & & & & & \\
\hline $\begin{array}{l}\text { BAS1 } \\
\text { Os02g0537700 }\end{array}$ & Chr 2 & Q6ER94 & $\begin{array}{l}\text { Knockout/ } \\
\text { overexpression } \\
\text { gene transfer }\end{array}$ & $\begin{array}{l}\text { CRISPR/Cas9- } \\
\text { gene transfer }\end{array}$ & $\begin{array}{l}\text { Overexpression causes stomatal closing and } \\
\text { increased K+-deficiency tolerance. Knockout results } \\
\text { in defects in the leaves and the stomata openings. } \\
\text { The protein is localized in the chloroplast, reducing } \\
\text { hydrogen peroxide and organic hydroperoxides to } \\
\text { water and alcohols. }\end{array}$ & $\begin{array}{l}\text { (Mao et } \\
\text { al., 2018) }\end{array}$ \\
\hline $\begin{array}{l}\text { HGW } \\
\text { Os06g0160400 }\end{array}$ & Chr 6 & B6TN35 & Natural & $\begin{array}{l}\text { Spontaneous } \\
\text { mutation }\end{array}$ & $\begin{array}{l}\text { Is a key regulator of heading date and grain weight. } \\
\text { Encodes a protein with a UBA domain. Homozygous } \\
\text { null mutant is embryonic lethal. }\end{array}$ & $\begin{array}{l}\text { (Li et al., } \\
2012 \text { ) }\end{array}$ \\
\hline
\end{tabular}

Page 17/23 
heading and

grain weight

heading date-

and grain weight-

related protein

Table 5. Rice genes and mutations in traits such as oleic acid, color, fragrancy, and nitrogen use.

\begin{tabular}{|c|c|c|c|c|c|}
\hline Gene & Position & Protein & $\begin{array}{l}\text { Obtained } \\
\text { Mutation }\end{array}$ & Method & Trait details \\
\hline $\begin{array}{l}\text { FAD2 } \\
\text { Os02g0716500 } \\
\text { fatty acid } \\
\text { desaturase } 2\end{array}$ & Chr 2 & Q6ZGW6 & Knockout & $\begin{array}{l}\text { CRISPR/Cas9- } \\
\text { RNAi }\end{array}$ & Increased oleic acid (twice) and decreased linoleic acid content. \\
\hline $\begin{array}{l}\text { Osor } \\
\text { Os02g0651300 }\end{array}$ & Chr 2 & Q6H3Y3 & Knockout & CRISPR/Cas9 & $\beta$-carotene accumulation resulting in orange-colored calli. \\
\hline $\begin{array}{l}\text { BADH2 } \\
\text { Os08g0424500 }\end{array}$ & Chr 8 & A0A0P0XG36 & Knockout & CRISPR/Cas9 & $\begin{array}{l}\text { Betaine aldehyde dehydrogenase 2, prevents the formation of 2-acetyl-1-pyrro } \\
\text { which gives fragrant rice its aromatic properties. Change in fragrance. }\end{array}$ \\
\hline $\begin{array}{l}\text { OsNPF6.1 } \\
\text { Os01g0103100 } \\
\text { Nitrate } \\
\text { transporter }\end{array}$ & Chr 1 & Q9FTZ3 & $\begin{array}{l}\text { HapB, } \\
160 \mathrm{Gly} \\
\text { to Asp } \\
\text { and two } \\
\text { additional } \\
\text { CACG } \\
\text { motifs at } \\
\text { the } \\
\text { promoter } \\
-0.5 \mathrm{~Kb} \\
\text { and }-1 \mathrm{~kb}\end{array}$ & $\begin{array}{l}\text { Natural, } \\
\text { validation } \\
\text { with } \\
\text { CRISPR/CAS9 } \\
\text { Knockout- } \\
\text { Gene transfer }\end{array}$ & Nitrate transporter OsNPF6.1 is more efficient and has increased expression. \\
\hline $\begin{array}{l}\text { OsNAC42 } \\
\text { Os09g0493700 } \\
\text { NUE (nitrogen } \\
\text { use efficiency)- } \\
\text { related } \\
\text { transcription } \\
\text { factor }\end{array}$ & Chr 9 & Q0J0L8 & $\begin{array}{l}\text { Natural- } \\
\text { Knockout }\end{array}$ & $\begin{array}{l}\text { Natural, } \\
\text { validation } \\
\text { with } \\
\text { CRISPR/CAS9 } \\
\text { Knockout- } \\
\text { lost-of- } \\
\text { function SNP } \\
\text { mutation } \\
\text { (Pro51 } \\
\text { changed to } \\
\text { Leu, P51L) }\end{array}$ & $\begin{array}{l}\text { Transcription factor OsNAC42 related to the expression of the nitrate transpor } \\
\text { Loss of function decreased expression of nitrate transporter OsNPF6.1 }\end{array}$ \\
\hline $\begin{array}{l}\text { OsNLP4 } \\
\text { Os09g0549450 } \\
\text { transcriptional } \\
\text { factor, } \\
\text { Promotion of } \\
\text { nitrogen use } \\
\text { efficiency } \\
\text { (NUE) }\end{array}$ & Chr 9 & AOAOPOXQL5 & Natural & $\begin{array}{l}\text { Natural, HapB } \\
\text { distributed in } \\
\text { South China, } \\
\text { India and } \\
\text { South-East } \\
\text { Asia } \\
\text { 131T (UTR), } \\
181 \text { (UTR), } \\
614 \mathrm{~A}, 842 \mathrm{~T} \text {, } \\
\text { 2889C, } \\
4662 \mathrm{~T} \text { (UTR), } \\
\text { 4674T(UTR), } \\
\text { 4888C (UTR) }\end{array}$ & $\begin{array}{l}\text { The gene is upregulated by nitrogen starvation. OsNLP4 binds to } \\
\text { the } \\
\text { NRE motif and promotes the expression of OsNiR that encodes a critical nitrite } \\
\text { nitrogen assimilation. }\end{array}$ \\
\hline
\end{tabular}

\section{Figures}




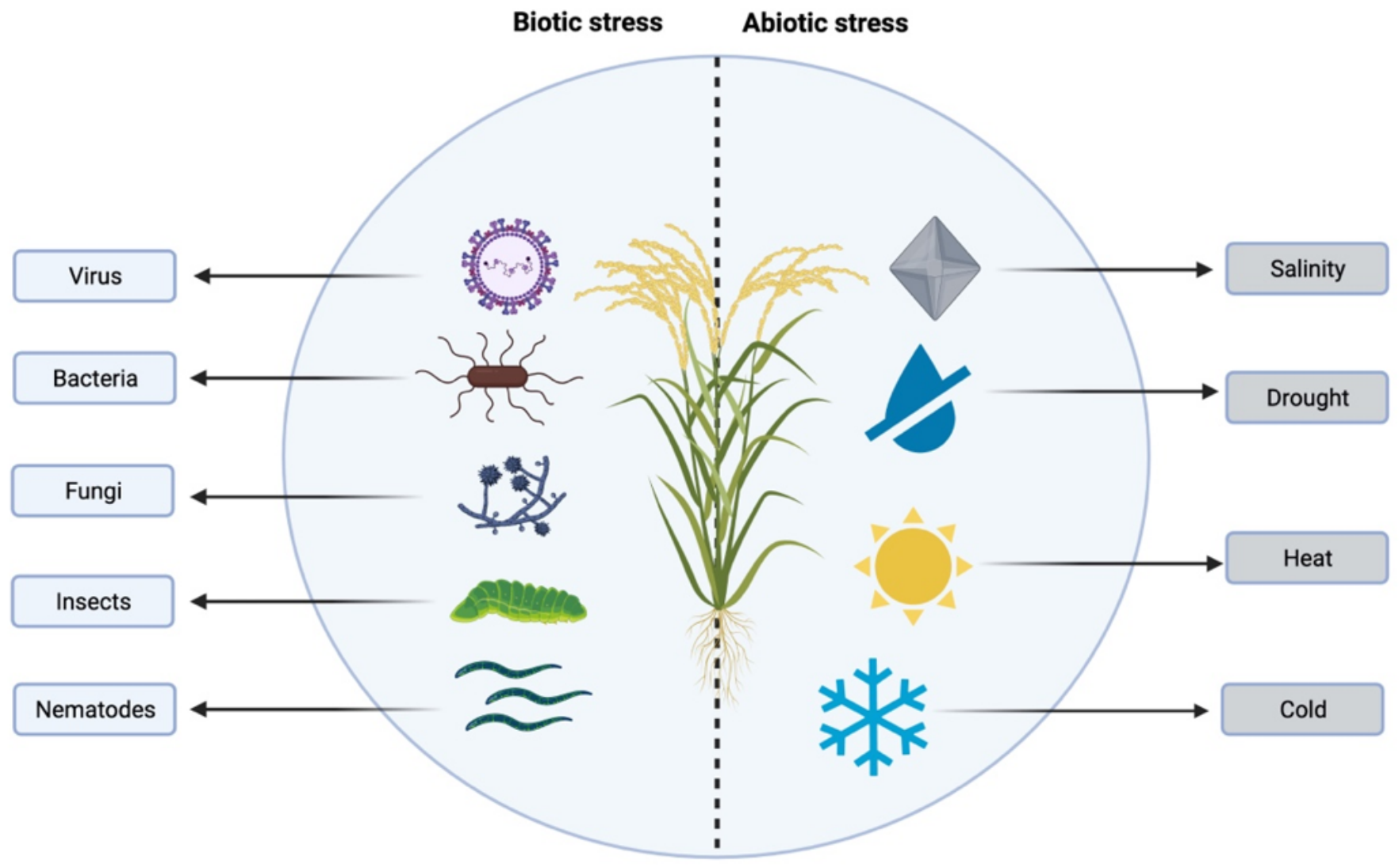

Figure 1

Representation of biotic and abiotic stress factors that affect rice production. Created with BioRender.com 


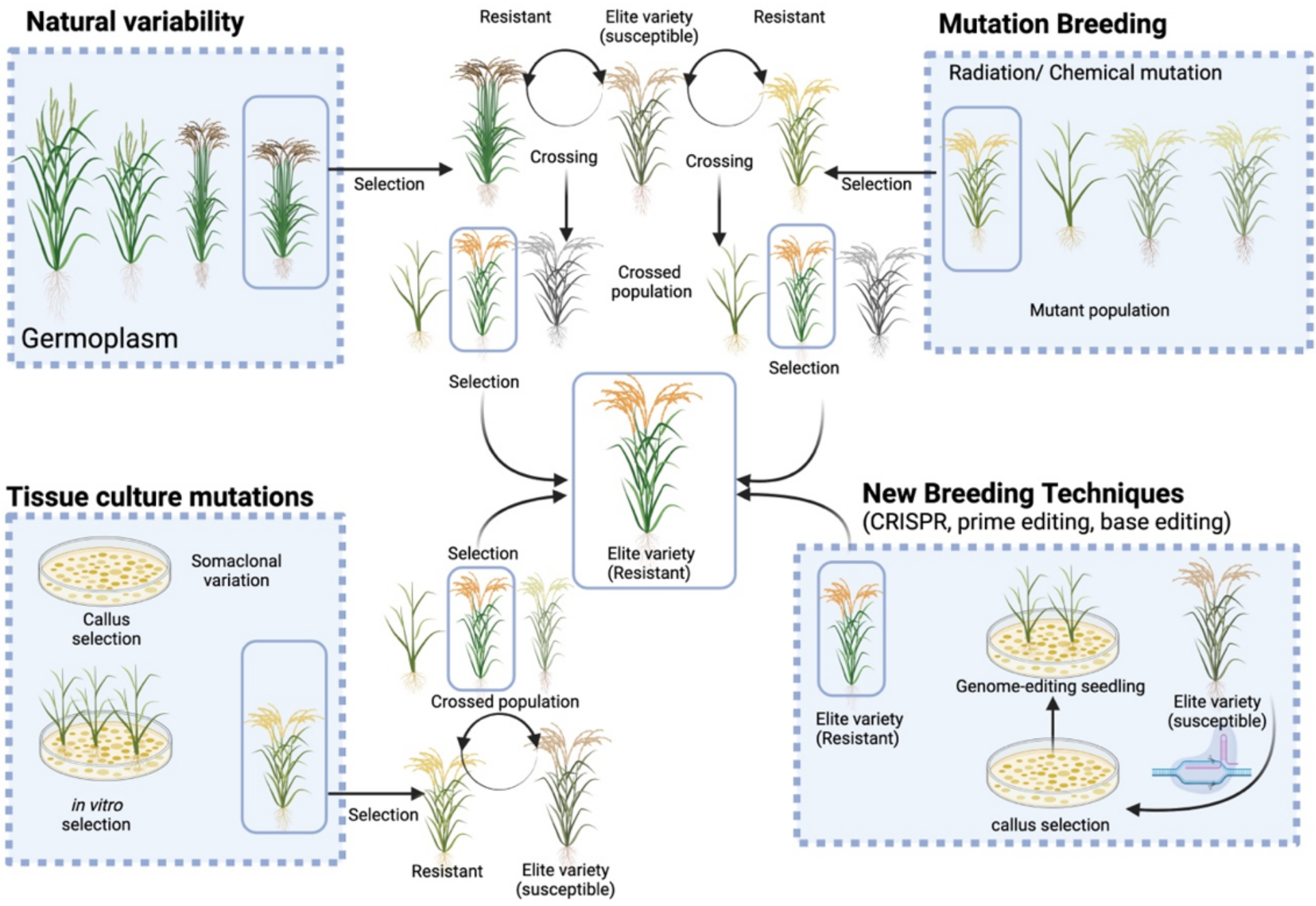

Figure 2

Schematic representation of different systems used for breeding rice: natural variability, mutation breeding, tissue culture mutation, and new breeding techniques. Created with BioRender.com 


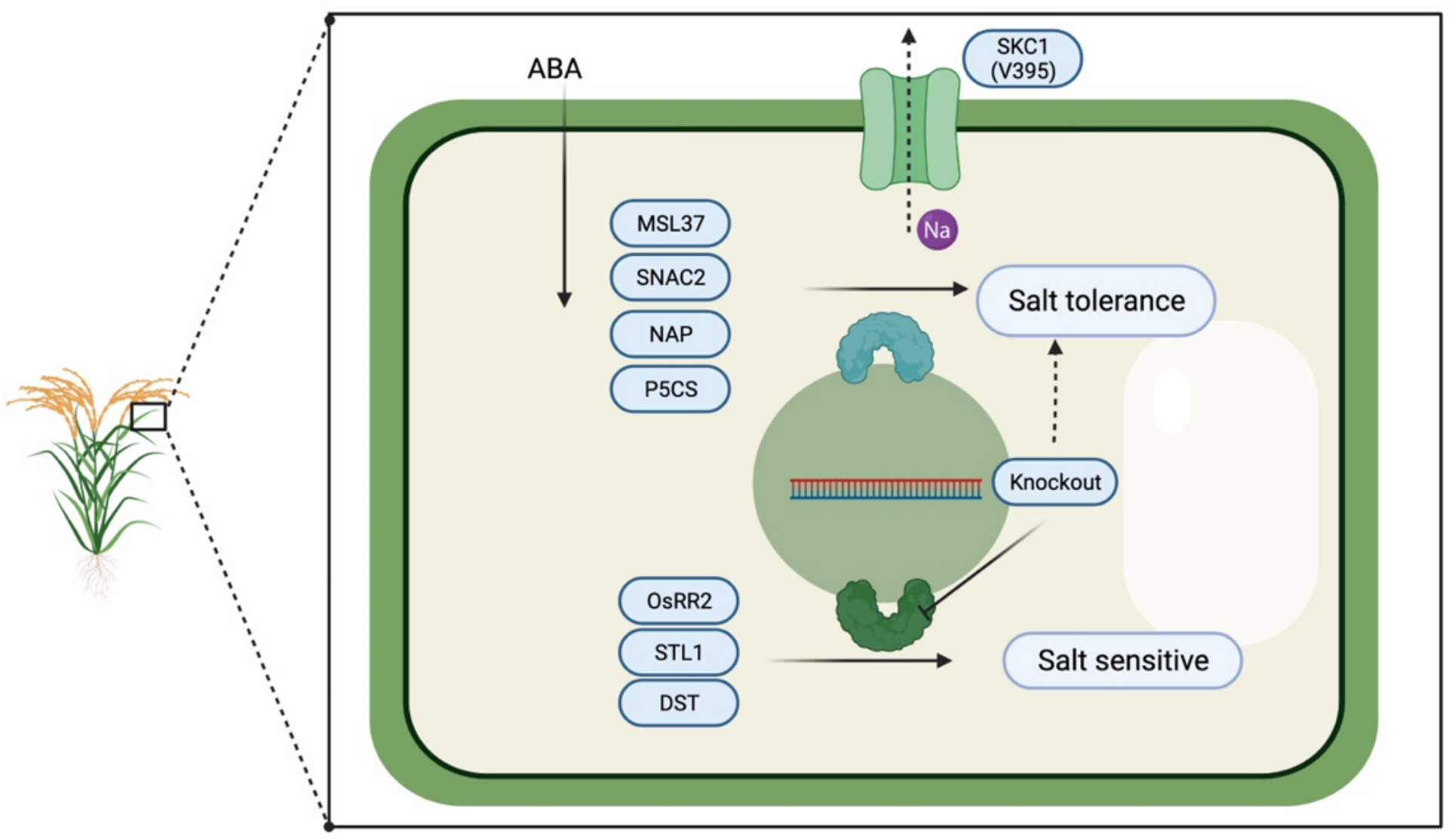

Figure 3

Representation of salt tolerance traits mediated by three different methods: 1) overexpression, 2) knockout of specific genes, and 3) particular sodium channels. Note that the first corresponds to transcription factors that trigger adaptive responses labeled MSL37, NAC2, NAP, and P5CS. The second is a knockout of those that result in salt sensitivity: OsRR2, STL1, DST; and the sodium channel SKC1 in rice. The third is the sodium channel SKC1 containing amino acid V395. Created with BioRender.com. 


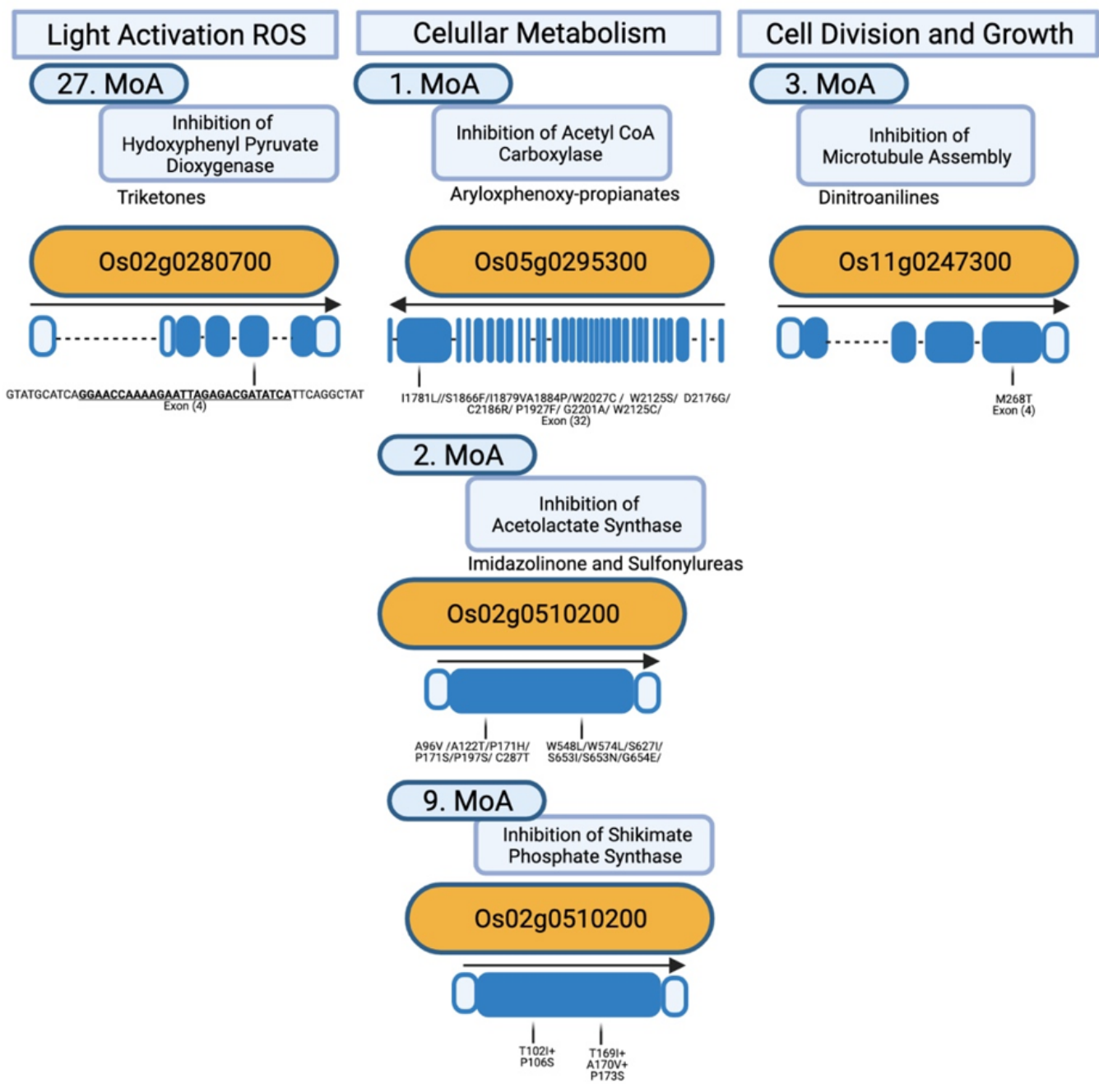

Figure 4

Representation of five rice genes and the corresponding mutation that results in herbicide tolerance. The genes are shown organized by their Mode of Action $(\mathrm{MoA})$. Note the name of the gene in orange circles, the exons in blue filled boxes and the corresponding untranslated exon regions in the blue empty boxes. Created with BioRender.com. 


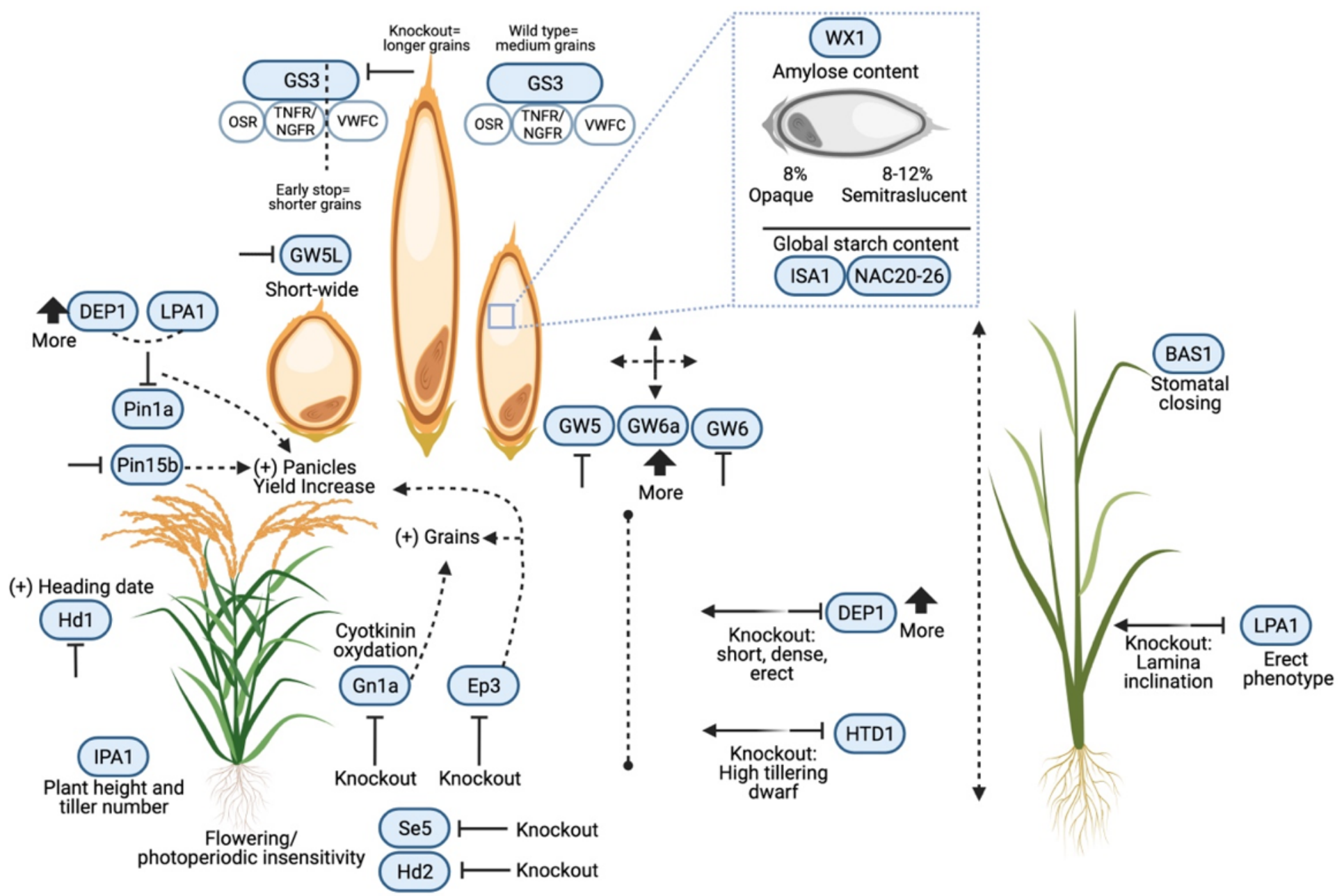

Figure 5

Representation of traits such as grain number, quality, weight and plant structure and gene relationships in rice. Note that heading and flowering are positively influenced by Se5, Hd2, and Hd1 knockout; structure by DEP1, HTD1, IPA1, LPA1, Pin1a, and Pin15b; grain size by Gn1a, and Ep3; grain size by GS3, GW6a, GW5, and GW5L; and grain starch by ISA1, NAC20-26, and WX1. Created with BioRender.com. 